Atmos. Chem. Phys., 13, 5831-5856, 2013

www.atmos-chem-phys.net/13/5831/2013/

doi:10.5194/acp-13-5831-2013

(c) Author(s) 2013. CC Attribution 3.0 License.

\title{
Black carbon physical properties and mixing state in the European megacity Paris
}

\author{
M. Laborde ${ }^{1, *}$, M. Crippa ${ }^{1}$, T. Tritscher ${ }^{1, * *}$, Z. Jurányi ${ }^{1, * * *}$, P. F. Decarlo ${ }^{1,{ }^{* * * *}}$, B. Temime-Roussel ${ }^{2}$, N. Marchand ${ }^{2}$, \\ S. Eckhardt ${ }^{3}$, A. Stohl ${ }^{3}$, U. Baltensperger ${ }^{1}$, A. S. H. Prévôt ${ }^{1}$, E. Weingartner ${ }^{1}$, and M. Gysel ${ }^{1}$ \\ ${ }^{1}$ Laboratory of Atmospheric Chemistry, Paul Scherrer Institute, Villigen PSI, Switzerland \\ ${ }^{2}$ Aix-Marseille Université, CNRS, LCE FRE 3416, 13331, Marseille, France \\ ${ }^{3}$ NILU - Norwegian Institute for Air Research, Kjeller, Norway \\ *now at: AerosolConsultingML GmbH, Ennetbaden, Switzerland \\ ** now at: TSI GmbH, Particle Instruments, Aachen, Germany \\ *** now at: Institute of Aerosol and Sensor Technology, University of Applied Sciences Northwestern Switzerland, \\ Windisch, Switzerland \\ **** now at: Department of Civil, Architectural, and Environmental Engineering, and Department of Chemistry, \\ Drexel University, Philadelphia, PA, USA
}

Correspondence to: M. Gysel (martin.gysel@psi.ch)

Received: 9 August 2012 - Published in Atmos. Chem. Phys. Discuss.: 24 September 2012

Revised: 18 April 2013 - Accepted: 22 April 2013 - Published: 14 June 2013

\begin{abstract}
Aerosol hygroscopicity and refractory black carbon $(\mathrm{rBC})$ properties were characterised during wintertime at a suburban site in Paris, one of the biggest European cities. Hygroscopic growth factor (GF) frequency distributions, characterised by distinct modes of more-hygroscopic background aerosol and non- or slightly hygroscopic aerosol of local (or regional) origin, revealed an increase of the relative contribution of the local sources compared to the background aerosol with decreasing particle size. BC-containing particles in Paris were mainly originating from fresh traffic emissions, whereas biomass burning only gave a minor contribution. The mass size distribution of the $\mathrm{rBC}$ cores peaked on average at an $\mathrm{rBC}$ core mass equivalent diameter of $D_{\mathrm{MEV}} \approx 150 \mathrm{~nm}$. The BC-containing particles were moderately coated (coating thickness $\Delta_{\text {coat }} \approx 33 \mathrm{~nm}$ on average for $\mathrm{rBC}$ cores with $D_{\mathrm{MEV}}=180-280 \mathrm{~nm}$ ) and an average mass absorption coefficient (MAC) of $\sim 8.6 \mathrm{~m}^{2} \mathrm{~g}^{-1}$ at the wavelength $\lambda=880 \mathrm{~nm}$ was observed.

Different time periods were selected to investigate the properties of BC-containing particles as a function of source and air mass type. The traffic emissions were found to be non-hygroscopic $(\mathrm{GF} \approx 1.0)$, and essentially all particles with a dry mobility diameter $\left(D_{0}\right)$ larger than $D_{0}=110 \mathrm{~nm}$ contained an $\mathrm{rBC}$ core. $\mathrm{rBC}$ from traffic emissions was
\end{abstract}

further observed to be uncoated within experimental uncertainty $\left(\Delta_{\text {coat }} \approx 2 \mathrm{~nm} \pm 10 \mathrm{~nm}\right.$ ), to have the smallest $\mathrm{BC}$ core sizes (maximum of the $\mathrm{rBC}$ core mass size distribution at $\left.D_{\mathrm{MEV}} \approx 100 \mathrm{~nm}\right)$ and to have the smallest MAC $\left(\sim 7.3 \mathrm{~m}^{2} \mathrm{~g}^{-1}\right.$ at $\left.\lambda=880 \mathrm{~nm}\right)$.

The biomass burning aerosol was slightly more hygroscopic than the traffic emissions (with a distinct slightlyhygroscopic mode peaking at $\mathrm{GF} \approx 1.1-1.2)$. Furthermore, only a minor fraction $(\leq 10 \%)$ of the slightly-hygroscopic particles with $1.1 \leq \mathrm{GF} \leq 1.2$ (and $D_{0}=265 \mathrm{~nm}$ ) contained a detectable $\mathrm{rBC}$ core. The $\mathrm{BC}$-containing particles from biomass burning were found to have a medium coating thickness as well as slightly larger mean $\mathrm{rBC}$ core sizes and MAC values compared to traffic emissions.

The aerosol observed under the influence of aged air masses and air masses from Eastern Continental Europe was dominated by a more-hygroscopic mode peaking at $\mathrm{GF} \approx 1.6$. Most particles $(95 \%)$, in the more-hygroscopic mode at $D_{0}=265 \mathrm{~nm}$, did not contain a detectable $\mathrm{rBC}$ core. A significant fraction of the BC-containing particles had a substantial coating with non-refractory aerosol components. MAC values of $\sim 8.8 \mathrm{~m}^{2} \mathrm{~g}^{-1}$ and $\sim 8.3 \mathrm{~m}^{2} \mathrm{~g}^{-1}$ at $\lambda=880 \mathrm{~nm}$ and mass mean $\mathrm{rBC}$ core diameters of $150 \mathrm{~nm}$ and $200 \mathrm{~nm}$ were observed for the aged and continental air 
mass types, respectively. The reason for the larger $\mathrm{rBC}$ core sizes compared to the fresh emissions - transport effects or a different $\mathrm{rBC}$ source - remains unclear.

The dominant fraction of the $\mathrm{BC}$-containing particles was found to have no or very little coating with non-refractory matter. The lack of coatings is consistent with the observation that the BC-containing particles are non- or slightlyhygroscopic, which makes them poor cloud condensation nuclei. It can therefore be expected that wet removal through nucleation scavenging is inefficient for fresh BC-containing particles in urban plumes. The mixing-state-specific cloud droplet activation behaviour of BC-containing particles including the effects of atmospheric aging processes should be considered in global simulations of atmospheric BC, as the wet removal efficiency remains a major source of uncertainty in its life-cycle.

\section{Introduction}

Particles emitted during incomplete combustion of biofuel, fossil fuel and open biomass burning are composed of different amounts of black carbon (BC; also referred to as refractory carbon or elemental carbon; Petzold et al., 2013), primary organic matter (POM) and inorganic salts depending on the sources. Atmospheric BC strongly absorbs sunlight at all wavelengths warming up the surrounding air and, therefore, the climate (Jacobson, 2001; Chung and Seinfeld, 2002; Ramanathan and Carmichael, 2008; Bond et al., 2013). In addition, when embedded in mixed phase or ice clouds, BC-containing particles modify the cloud properties, making them relevant for the understanding of the aerosol indirect effect's calculation (DeMott et al., 1999). Unlike most greenhouse gases, BC-containing particles have a short lifetime in the atmosphere and are estimated to be removed via wet deposition within 5-11 days (Koch et al., 2009), making the reduction in BC-containing particle emissions an attractive option to mitigate global warming (Shindell et al., 2012). However, a more accurate lifetime description is needed to assess the influence of the BC-containing particles on the Earth's radiative balance using three-dimensional models (Solomon et al., 2007).

The incorporation of BC-containing particles into cloud droplets through droplet nucleation or coagulation with existing droplets is a main removal mechanism of BC (Vignati et al., 2010). The ability of BC-containing particles to act as cloud condensation nuclei $(\mathrm{CCN})$ depends on their size and on the relative amount of water-soluble coatings (Dusek et al., 2006; Rose et al., 2011). The composition of combustion particles is tightly linked to their origin, i.e., they can be emitted as pure BC or along with POM or inorganic compounds (Chirico et al., 2010; Heringa et al., 2011). Further non-refractory matter is acquired by the BC-containing particles through ageing processes in the atmosphere, includ- ing condensation of compounds with sufficiently low volatility (organic or inorganic), coagulation and cloud processing (Cozic et al., 2007; Kuwata and Kondo, 2008; Schwarz et al., 2008b).

As a result of this ageing, the BC-containing particles acquire coatings which make them more hygroscopic and more CCN active (Kuwata et al., 2009; Tritscher et al., 2011). In addition, the mass absorption coefficient (MAC) of BC is size dependent and is amplified by coatings of non-refractory matter or water at high relative humidity, thereby resulting in a stronger direct effect on the Earth's radiative balance (Schnaiter et al., 2005). The measurement of BC core size and mixing state is, therefore, of importance in order to better understand the $\mathrm{BC}$ removal mechanism and to model the climate impacts of BC.

The mixing state of atmospheric $\mathrm{BC}$ is, however, difficult to measure and previous studies are rare. For example, the aerosol's mixing state can be determined using a hygroscopicity tandem differential mobility analyser (HTDMA), as summarised by Swietlicki et al. (2008) in their review study, or by the combined volatility hygroscopicity TDMA (VHTDMA) technique (e.g., Johnson, 2005). A monodisperse measurement of the $\mathrm{CCN}$ concentration using a continuousflow cloud condensation nuclei counter (CCNC) can also be used to obtain information on the mixing state of the aerosol (e.g., Rose et al., 2011; Jurányi et al., 2013). However, these two methods can only distinguish between particles of different hygroscopicity, whereas different compounds or different mixtures with equal hygroscopicity remain unresolved. Consequently, no information on the $\mathrm{BC}$ mixing state can be obtained using these techniques.

The aerosol time-of-flight mass spectrometer (ATOFMS; Sullivan and Prather, 2005) and similar instruments can provide information on the size-resolved chemical composition and degree of internal mixing state of absorbing particles with diameters under vacuum $\left(D_{\text {va }}\right.$; DeCarlo et al., 2004) between $100-3000 \mathrm{~nm}$. Healy et al. (2012) used the ATOFMS to retrieve the mixing state of elemental carbon (EC) in Paris. The term EC is here employed instead of BC as the ATOFMS uses mass spectrometry rather than light absorption as the method of detection. In Paris, the smaller EC-containing particles $\left(D_{\mathrm{va}} \leq 400 \mathrm{~nm}\right)$ were mainly externally mixed, indicating local or regional sources, while bigger EC-containing particles $D_{\mathrm{va}} \geq 400 \mathrm{~nm}$ ) were mainly internally mixed with nitrate compounds, indicating medium- to long-range transport.

More detailed information on the mixing state of $\mathrm{BC}$ can be obtained by combining multiple instruments. Herich et al. (2008) coupled an ATOFMS in series to a HTDMA in order to determine the mixing state of EC at the urban site Zurich (Switzerland) and at the high alpine site Jungfraujoch (Switzerland). In Zurich, EC-containing particles were found to be mainly internally mixed, but still with the lowest affinity to water while no significant enhancement of EC at low GF could be found at the Jungfraujoch. Kuwata 
and Kondo (2008) showed with volatility TDMA (VTDMA) measurements that the aerosol is often an external mixture of less- and more-volatile particles. Parallel monodisperse $\mathrm{CCN}$ measurements revealed a strong correlation between the $\mathrm{CCN}$-inactive and the less-volatile particles, which are most likely BC-containing particles.

The single particle soot photometer (SP2; Stephens et al., 2003) allows the determination of the mixing state of BCcontaining particles within the atmospherically relevant BC size range (Schwarz et al., 2008a; Shiraiwa et al., 2008). McMeeking et al. (2011a) coupled it in series to a HTDMA and found that the dominant fraction of BC-containing particles, at an urban site in Manchester (UK) were non- or slightly hygroscopic particles. As a result, BC is expected to be much less CCN active than most of the BC free particles of equal size (at equal supersaturation).

With more than half of the world population living in cities (http://www.who.int/gho/urban_health/situation_trends/ urban_population_growth_text/en/index.html), BC emitted in cities represents an important part of the total $\mathrm{BC}$ emissions and an important health hazard. Several studies performed in cities have shown that $\mathrm{BC}$ is emitted uncoated and that they gain coating after several hours although internally mixed BC can also be found in cities when transported from other places (Shiraiwa et al., 2008; Cheng et al., 2009; McMeeking et al., 2011b).

Paris, second largest city in Europe (after London), holds about $20 \%$ of France's population, but only a few studies have characterised the $\mathrm{BC}$ properties there (Liousse and Cachier, 1992; Ruellan and Cachier, 2001; Sciare et al., 2010, 2011; Healy et al., 2012). Liousse and Cachier (1992) highlighted the influence of meteorological conditions on BC concentrations while Ruellan and Cachier (2001) observed a strong influence of traffic on the BC concentration in downtown Paris. In addition, Sciare et al. $(2010,2011)$ found a strong local pattern of the carbonaceous aerosol.

In this study, a measurement campaign was carried out in the agglomeration of Paris as part of the MEGAPOLI European project (megacity: emission, urban, regional and global atmospheric pollution and climate effects, and integrated tools for assessment and mitigation; www.megapoli.info) where the physical properties, mixing state and hygroscopicity of BC-containing particles were characterised.

\section{Methods}

\subsection{Single particle soot photometer (SP2)}

\subsubsection{Description}

The SP2, manufactured by Droplet Measurement Technology, Boulder, CO, USA, has previously been described in detail elsewhere (Stephens et al., 2003; Schwarz et al., 2006). In short, the SP2 uses laser-induced incandescence to quantify the refractory black carbon (rBC) mass in single particles. A continuous intra-cavity laser beam (Nd:YAG; $\lambda=1064 \mathrm{~nm}$ ) is used to heat BC-containing particles to their vaporisation point. The peak intensity of the thermal radiation (measured at two different wavelength ranges), emitted by the incandescent $\mathrm{rBC}$ core and detected by the SP2, is linearly proportional to the mass of refractory black carbon (rBC) in the particle (see Sect. 2.2 for more details about the terminology as well as a comparison between collocated $\mathrm{rBC}$ and EC measurements). This method is unbiased by the presence of non-refractory matter, which vaporises before the BC vaporisation temperature of $T \sim 4000^{\circ} \mathrm{C}$ and the peak intensity of the incandescent light are reached (Moteki and Kondo, 2007). This method allows the quantification, with $100 \%$ efficiency, of $\mathrm{rBC}$ mass in individual particles between $\sim 0.5-$ $50 \mathrm{fg} \mathrm{rBC}$ per particle, corresponding to $\mathrm{rBC}$ cores with mass equivalent diameters ( $D_{\mathrm{MEV}}$ ) between $\sim 80-500 \mathrm{~nm}$ (assuming a void free material density of $1800 \mathrm{~kg} \mathrm{~m}^{-3}$ for the $\mathrm{rBC}$ core).

\subsubsection{Calibration}

Prior to the measurement field campaign, the SP2 was adjusted following the recommended adjustments detailed in Laborde et al. (2012b). The incandescence signal was calibrated (three times, at the beginning, half way through and at the end of the measurement campaign) using mobility size selected fullerene soot particles (Alpha Aesar; \#FS12S011) which is recommended for SP2 calibration as it gives similar SP2 responses as ambient rBC (Moteki and Kondo, 2010; Baumgardner et al., 2012; Laborde et al., 2012a). The fullerene soot particles were selected by mobility diameter using a differential mobility analyser (DMA) and the corresponding particle masses were calculated using the effective density data provided in Gysel et al. (2011). The scattering signal was calibrated twice (at the beginning and half way through the measurement campaign) using spherical polystyrene latex size standards with a diameter of $269 \mathrm{~nm}$ (Thermo Scientific, formerly Duke Scientific). More details on SP2 calibration and calibration standard material can be found in Baumgardner et al. (2012), Laborde et al. (2012b) and Gysel et al. (2011).

\subsubsection{Data analysis and uncertainties}

The rBC mass in individual particles is determined from the peak intensity of the incandescence signal applying the fullerene soot calibration described in Sect. 2.1.2. Mass equivalent $\mathrm{rBC}$ core diameters, $D_{\mathrm{MEV}}$, are calculated from the measured $\mathrm{rBC}$ mass assuming a void-free density of $1800 \mathrm{~kg} \mathrm{~m}^{-3}$. The rBC core mass size distributions, derived from 30-min intervals of single particle data, were fitted with a lognormal function in order to estimate the $\mathrm{rBC}$ mass below the SP2's detection limit. All rBC mass concentrations presented here are corrected for this missing mass, which 
accounted for less than $10 \%$ of the total estimated rBC mass on average.

In addition to the rBC mass, the measurement of the light scattered by the particle allows the determination of its scattering cross section. However, the scattering cross section of BC-containing particles decreases soon after they enter the laser beam due to thermal heating and evaporation of the coating. The initial scattering cross section can only be determined from the leading edge of the scattering signal (LEO-fit, Gao et al., 2007). Here the leading edge could only be considered up to $1 \%$ of maximal laser intensity without interference from coating evaporation. The particle's optical diameter is then inferred from the measured scattering cross section using a Mie model that idealises the morphology of the BC-containing particles as a spherical rBC core with a concentric shell of coating matter (Schwarz et al., $2008 b)$. Refractive indices for both the non-refractory matter $\left(n_{\text {coat }}\right)$ and the rBC core $\left(n_{\mathrm{BC} \text { core }}\right)$ have to be assumed in order to do so. The coating thickness, $\Delta_{\text {coat }}$, of the rBC core by non-refractory matter is then calculated as the difference between the whole particle optical radius and the $\mathrm{rBC}$ core mass equivalent radius.

Inadequacy of the assumption made for the Mie calculations regarding particle morphology (sphericity) as well as refractive indices of the $\mathrm{rBC}$ core $\left(n_{\mathrm{BC}}\right.$ core $)$ and the coating $\left(n_{\text {coat }}\right)$ can result in systematically biased optical sizes and derived coating thickness values. The LEO-fit method introduces additional random noise.

Purely scattering particles can be assumed to be spherical, leaving the choice of $n_{\text {coat }}$ as the main source of uncertainty. Here we measured size-selected ambient samples behind a DMA in order to identify the optimum $n_{\text {coat }}$ value. Agreement between optical diameter and mobility diameter was achieved for $n_{\text {coat }}=1.5$, which is in the range of refractive indices of inorganic salts $\left(\left(\mathrm{NH}_{4}\right)_{2} \mathrm{SO}_{4}=1.51 ; \mathrm{NaCl}=1.53\right.$; Toon et al., 1976) and secondary organic aerosol $(\sim 1.44-$ 1.5; Schnaiter et al., 2003; Nakayama et al., 2010), at $\lambda=1064 \mathrm{~nm}$.

Uncoated BC-containing particles are known to be highly non-spherical aggregates of primary particles. However, Moteki et al. (2010) showed that the optical shape factor is not far away from unity for small size parameters (note, the SP2 uses a long wavelength compared to the size of the particles). Furthermore, a good agreement $( \pm 10 \%)$ between the optical diameter of the bare $\mathrm{rBC}$ core, as determined after coating evaporation and before incandescence, and the rBC core mass equivalent diameter was obtained using literature value of $n_{\mathrm{BC} \text { core }}=2.26+1.26 \mathrm{i}$ at $\lambda=1064 \mathrm{~nm}$ (Moteki et al., 2010). This result indicates reliable optical sizing of the bare rBC cores with the above assumptions. The resulting systematic uncertainty of coating thickness values of uncoated $\mathrm{BC}$-containing particles with a mass equivalent diameter of $200 \mathrm{~nm}$ is estimated to be $\pm 10 \mathrm{~nm}$ at $\Delta_{\text {coat }}=0 \mathrm{~nm}$. Negative coating thickness values within this tolerance are thus not a concern. It is important to note that this uncertainty refers to the average over many particles, as the coating thickness value determined for an individual particle is associated with additional random noise. Further discussion on the uncertainties associated to the coating thickness is available elsewhere (Schwarz et al., 2008b; Laborde et al., 2012b).

Thickly coated BC-containing particles are also expected to be almost spherical. This is not only due to the condensing material filling the voids of the $\mathrm{BC}$ aggregates, but also due to compaction of the aggregates induced by capillary forces through the condensing material (Weingartner et al., 1995). The optical sizing of BC-containing particles with less than $\sim 35 \%$ rBC volume fraction, derived with the above assumptions for $n_{\text {coat }}$ and $n_{\text {BCcore }}$, was also successfully verified against the mobility diameter of size-selected ambient samples. The mass equivalent diameter of the rBC core is also determined with high accuracy ( $\sim 10 \%$ uncertainty of rBC mass measurement; Laborde et al., 2012b). These results highlight the fact that accurate coating thickness is also obtained for thickly coated BC-containing particles.

BC-containing particles with medium to thin coating are less spherical than highly coated particles, but more spherical than uncoated particles. The accuracy of coating thickness values determined in these cases was not independently verified. However, it can be expected to be reasonably accurate too, as the assumption made in the Mie calculations performed well for uncoated and thickly coated BC-containing particles.

\subsection{Comparison of SP2 with Sunset OCEC analyser}

Different approaches are commonly used to measure the mass concentration of atmospheric "black carbon", which results in many different terms for essentially the same quantity (Petzold et al., 2013): elemental carbon (EC) is measured by thermal-optical methods, refractory black carbon (rBC) is measured by laser-induced incandescence and black carbon (BC) is measured by light absorption approaches (more recently the term equivalent black carbon, EBC, is promoted for BC mass inferred from light absorption measurements). However, these terms synonymously refer to pure carbon, which is the most refractory and light absorbing component of carbonaceous combustion particles. Kondo et al. (2011) have shown that agreement between EC, rBC and EBC can be achieved (though additional measures to determine and stabilise the mass absorption coefficient of BC particles must be taken to make a quantitative interpretation of light absorption measurements possible).

Collocated EC and rBC measurements are available in this study. A high-volume sampler with a $\mathrm{PM}_{2.5}$ cut-off was used to collect the aerosol on quartz (Tissuquartz ${ }^{\mathrm{TM}}$ ) filters with a time resolution of $12 \mathrm{~h}$. Punches of the filters $\left(1.5 \mathrm{~cm}^{2}\right)$ were analysed by the Laboratoire de Glaciologie et de Géophysique de l'Environnement (LGGE, Grenoble) for EC using a thermal-optical Sunset OCEC analyser (Bae et al., 2004) with applying the EUSAAR-II protocol (Cavalli 


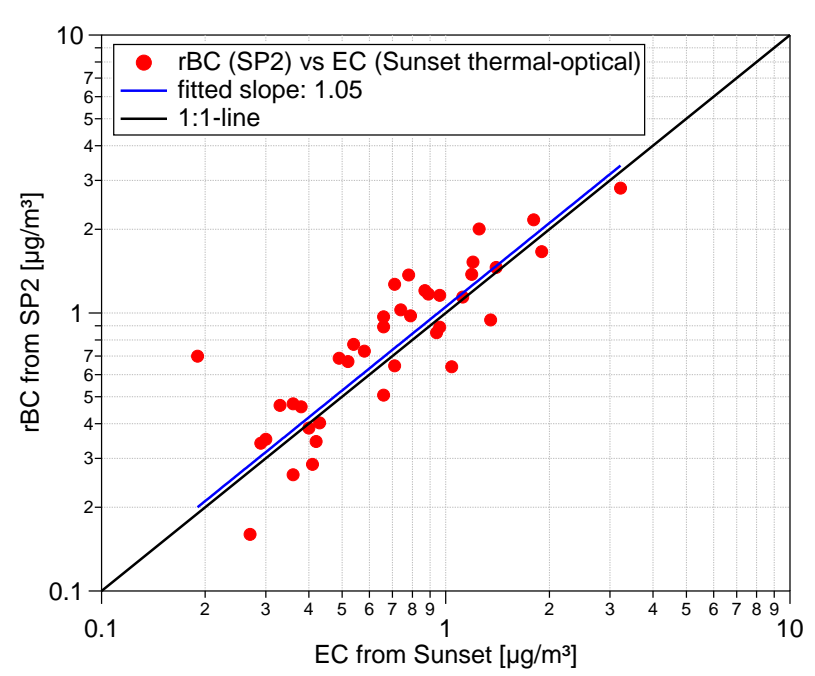

Fig. 1. Comparison between EC from the Sunset OCEC analyser and $\mathrm{rBC}$ from the SP2 for the whole campaign (12 $\mathrm{h}$ average values).

et al., 2010). Figure 1 shows a comparison between EC (Sunset OCEC analyser) and rBC (SP2) concentrations. Excellent agreement is achieved between the two methods with a fitted slope of 1.05 , which is well within the experimental uncertainty of either method. This indicates that the SP2 covered the relevant part of the $\mathrm{BC}$ size distribution and it confirms the result from Kondo et al. (2011) that $\mathrm{EC}$ and $\mathrm{rBC}$ mass concentration measurements are directly comparable.

\subsection{Hygroscopicity tandem differential mobility analyser (HTDMA)}

The HTDMA used in this study has previously been described in detail (Tritscher et al., 2011). Briefly, the aerosol is dried to a low relative humidity $(\mathrm{RH} \leq 10 \%)$ and brought to charge equilibrium with a ${ }^{85} \mathrm{Kr}$ bipolar charger before a first DMA (custom-built long DMA similar to TSI 3081) is used to select a quasi-monodisperse sample with a well defined dry mobility diameter $\left(D_{0}\right)$ which is then humidified, to high $\mathrm{RH}$ (plug flow residence time of $26 \mathrm{~s}$ ). A second DMA scans the humidified particles by mobility diameter $\left(D_{\mathrm{RH}}\right)$, which are then counted with a condensation particle counter (CPC, TSI 3022A). The hygroscopic growth factor of a particle is defined as $\mathrm{GF}(\mathrm{RH})=D_{\mathrm{RH}} / D_{0}$. The DMAs and humidifier are situated in a temperature controlled housing at $20^{\circ} \mathrm{C}$ to guarantee accurate RH control and GF measurement.

Details on the data inversion procedures for HTDMA data are provided in Gysel et al. (2009). Briefly, sizing differences between the first and second DMA are corrected for with dry measurements of ambient air. Accurate operation of the HTDMA was verified with pure ammonium sulphate aerosol particles. The RH and growth factor accuracy are typically better than $\pm 1.2 \%$ and $\pm 2 \%$, respectively. The growth factor probability density function (GF-PDF) was retrieved from the raw data using the TDMAinv inversion algorithm (Gysel et al., 2009).

The HTDMA was operated at a nominal RH of $90 \%$. Only measurements taken between 88 and $92 \%$ RH were considered in the results and all inverted GF-PDFs were recalculated from the measured RH to the nominal RH of $90 \%$, following the approach described in Gysel et al. (2009). Particles with dry mobility diameters of $D_{0}=35,50,75,110,165$ and $265 \mathrm{~nm}$ were sequentially monitored, but only results for $D_{0}=110,265 \mathrm{~nm}$ are presented here due to the overlap with the SP2 detection range.

\subsection{Additional dataset used}

The chemical composition of the non-refractory (at $T=600^{\circ} \mathrm{C}$ ) components of particles (such as organics, sulfate, nitrate, ammonium and chloride) with diameters $D_{\mathrm{p}} \leq 1 \mu \mathrm{m}\left(\mathrm{NR}-\mathrm{PM}_{1}\right)$ was determined using a high resolution time-of-flight aerosol mass spectrometer (HR-ToFAMS; collection efficiency 0.5; DeCarlo et al., 2006; Aerodyne Research Inc.). Positive matrix factorisation (PMF; Lanz et al., 2007; Ulbrich et al., 2009) was applied to the dataset and the following four factors were found to explain most of the organic concentration's variability: biomass burning organic aerosol (BBOA), oxidised organic aerosol (OOA), hydrocarbon-like organic aerosol (HOA) and organic aerosol from cooking origin (COA). In this study, the PMF factors are only used to identify periods with a dominant influence from different aerosol sources, while complete results from the HR-ToF-AMS dataset can be found elsewhere (Crippa et al., 2013). However, it is important to notice that a high correlation between the BBOA factor time series and both the levoglucosan time series (a typical biomass burning tracer) and the biomass burning BC concentration from the aethalometer model was observed, reinforcing the source apportionment results.

The light absorption coefficient of the aerosol was measured using an aethalometer (Magee scientific, AE-31) equipped with 7 quasi-monochromatic light emitting diodes (LEDs) as light sources $(\lambda=370,470,520,590,630,660$, $880,950 \mathrm{~nm}$ ). The measurement was corrected for the shadowing effect and filter loading using the method from Weingartner et al. (2003) (a $C=4.2$ was obtained from comparison with a multi angle absorption photometer, MAAP, during short periods, and $f=1.3$ was used). A single correction factor $C$ was used here for the entire measurement campaign due to a lack of MAAP data. Implications of this assumption will be discussed further down.

The aerosol size-distribution was measured using a custom-built scanning mobility particle sizer (SMPS) from the Paul Scherrer Institute (PSI), with an aerosol to sheath flow ratio of $1: 10$. The performance of this SMPS was successfully verified during an SMPS intercomparison campaign (Wiedensohler et al., 2012). 
A high sensitivity proton transfer reaction mass spectrometer (HS-PTRMS, Ionicon Analytik, Lindinger et al., 1998) was deployed during the intensive field campaign in order to quantify volatile organic compounds (VOCs). A 10-m Teflon tubing sampling line was installed on the roof of the building with a primary flow of $10 \mathrm{~L} \mathrm{~min}^{-1}$. During the campaign, 39 mass to charge ratios $(\mathrm{m} / \mathrm{z})$ were monitored with a temporal resolution of $2.5 \mathrm{~min}$, including the ions at $\mathrm{m} / \mathrm{z}=25,32$, $37,39,55,80$ used to control the HS-PTRMS performance (fragmentation, ionisation) while the 33 remaining $\mathrm{m} / \mathrm{z}$ ions monitored correspond to individual VOC's or sum of isomers. The transmission of the HS-PTRMS quadrupole was adjusted using the mean of 18 individual VOCs with certified concentration overlapping the mass range of the VOCs monitored within the field campaign. Within this study two VOC's measured by HS-PTRMS were considered: benzene $(\mathrm{m} / \mathrm{z}, 79)$ and toluene $(\mathrm{m} / \mathrm{z}, 93)$. The two selected VOCs were also individually calibrated in the range $0.2-8 \mathrm{ppbv}$ at $50 \%$ $\mathrm{RH}$ and are used here as an indicator of air mass age.

To identify the origin of sampled air masses, retroplumes were calculated using the Lagrangian particle dispersion model FLEXPART (Stohl et al., 1998, 2005). FLEXPART was driven with data from the European centre for mediumrange weather forecasts (ECMWF) with $0.18^{\circ}$ resolution over Europe ( $1^{\circ}$ over the rest of the globe). Retroplumes were calculated every three hours for the measurement site (site instrumental de recherche par télédetection atmosphérique, SIRTA) by releasing 60000 particles in a small box, centred at the measurement location and tracking them back in time for 20 days. The primary model output is an emission sensitivity, which is proportional to the particle residence time. Emission sensitivity was calculated for a passive tracer, not taking into account wet and dry deposition. The emission sensitivity value $\left(\mathrm{skg}^{-1}\right)$ is a measure for the simulated mixing ratio at the measurement site that a source of unit strength $\left(\mathrm{kg} \mathrm{s}^{-1}\right)$ would produce. The footprint sensitivities used here represent the pollution in the lowest model layer (0-100 $\mathrm{m}$ a.g.l.).

\subsection{Köhler theory}

The following method was used in order to calculate the theoretical curves discussed in Sect. 3.4. The equilibrium between a solution droplet and water vapour is described by Köhler theory (e.g., McFiggans et al., 2006). Petters and Kreidenweis (2007) introduced an empirical parameterisation to describe the relationship between GF and water activity $\left(a_{\mathrm{W}}\right)$ using a single hygroscopicity parameter $(\kappa)$.

$\mathrm{GF}\left(a_{\mathrm{w}}\right)=\left(1+\kappa \frac{a_{\mathrm{w}}}{1-a_{\mathrm{w}}}\right)^{1 / 3}$
The Köhler equation describes the relationship between water activity and equilibrium $\mathrm{RH}$ over a droplet:

$\exp \left(\frac{4 \sigma_{\mathrm{sol}} M_{\mathrm{w}}}{R T \rho_{\mathrm{w}} \mathrm{GF} D_{0}}\right)=\frac{\mathrm{RH}}{a_{\mathrm{w}}}$,

where $M_{\mathrm{w}}, \rho_{\mathrm{w}}$ are the molecular weight and the density of water, respectively, $R$ is the ideal gas constant, $T$ is the temperature in Kelvin, $\sigma_{\text {sol }}$ is the surface tension of the solution droplet and $D_{0}$ is the dry diameter of the particle. The equilibrium GF for a certain $\kappa$ and RH is obtained, for a certain $\kappa$ and $D_{0}$, by numerically solving Eqs. (1) and (2). $\sigma_{\text {sol }}$ is thereby assumed to be equal to the surface tension of pure water for all calculations.

The relative humidity is commonly expressed as supersaturation ( $\mathrm{SS}=\mathrm{RH}-1)$ in the context of cloud condensation nuclei $(\mathrm{CCN})$ activation. The critical supersaturation for $\mathrm{CCN}$ activation corresponds to the maximum equilibrium SS as a function of the GF, which is also obtained by numerically solving Eqs. (1) and (2), for a certain $\kappa$ and $D_{0}$.

The Zdanovski-Stokes-Robinson (ZSR) mixing rule, which has been shown to perform well for ambient aerosols (e.g., Gysel et al., 2007), can be used to calculate the hygroscopicity parameter $\kappa$ of a mixed particle from pure component properties. The kappa value of a mixed particle $\left(\kappa_{\text {mixed }}\right)$ becomes (Petters and Kreidenweis, 2007):

$\kappa_{\text {mixed }}=\sum_{i} \varepsilon_{i} \kappa_{i}$

where $\kappa_{i}$ is the hygroscopicity parameter of component $i$ and $\varepsilon_{i}$ its volume fraction in the dry mixed particle. The $\kappa$ value of the insoluble $\mathrm{rBC}$ core is 0 . Equation (3) simplifies then to:

$\kappa_{\text {mixed }}=\varepsilon_{\text {coat }} \kappa_{\text {coat }}=\left(1-\frac{\left(D_{\mathrm{MEV}}\right)^{3}}{\left(D_{\mathrm{MEV}}+2 \Delta_{\text {coat }}\right)^{3}}\right) \kappa_{\text {coat }}$

for coated BC-containing particles, where the suffix "coat" denotes the non-refractory coating. The growth factor and the critical supersaturation as a function of the coating thickness, shown in Fig. $15 \mathrm{e}-\mathrm{h}$ are then obtained by inserting $\kappa_{\text {mixed }}$ from Eq. (4) in Eqs. (1) and (2), followed by numerical solving, as described above.

\subsection{Measurement site and experimental setup}

As part of the MEGAPOLI project, three stationary measurement stations were chosen in greater Paris: one downtown (laboratoire d'hygiène de la ville de Paris, LHVP), one northeast of the city (golf de la poudrière) and one southwest of it at the SIRTA site. Additionally, mobile measurements were performed on-board of two aircrafts and two vans. This study focuses on the measurements performed from 15 January 2010 to 15 February 2010, on the SIRTA measurement platform (Haeffelin et al., 2005), situated in a suburban area $\sim 20 \mathrm{~km}$ southwest of Paris city centre (Fig. 2), on the Ecole Polytechnique campus. 


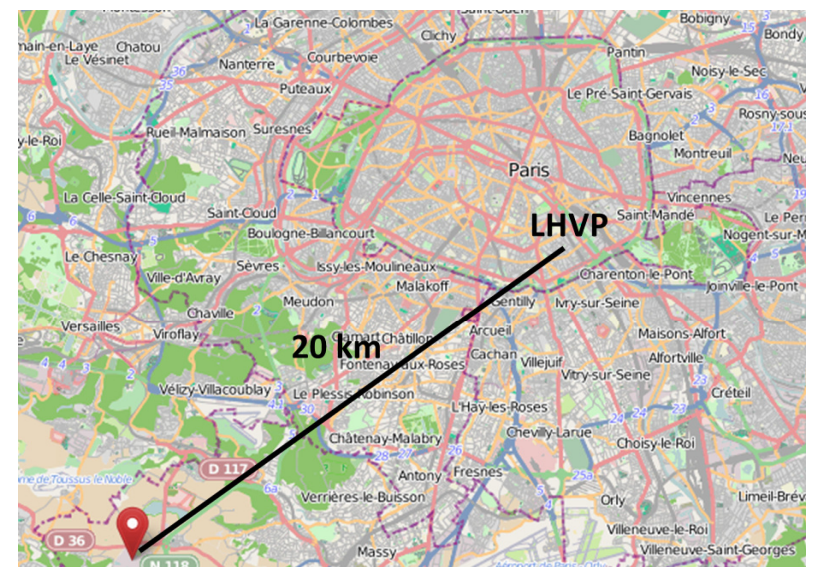

Fig. 2. SIRTA measurement platform, $20 \mathrm{~km}$ southwest of the other measurement station (LHVP), situated in Paris centre.
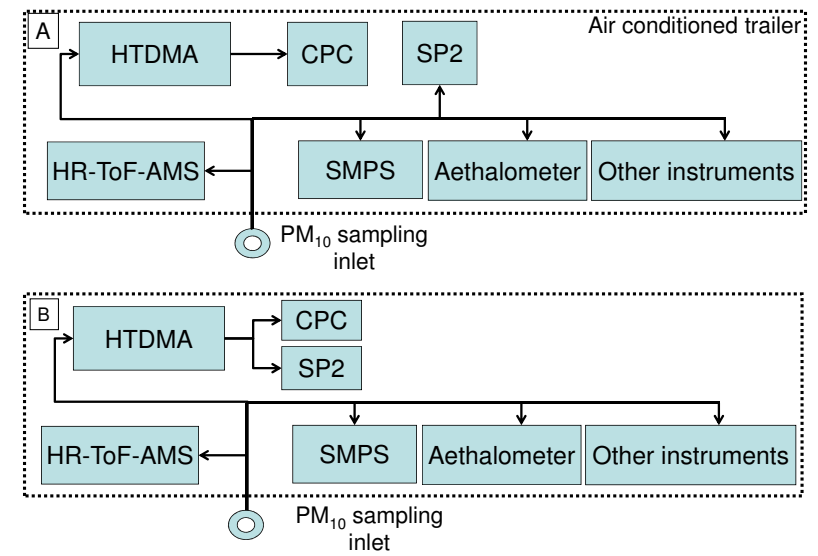

Fig. 3. Experimental setup during the majority of the measurement campaign (A) and during the period with coupled HTDMA-SP2 setup (B: 30-31 January).

The above-mentioned instruments (apart from the HSPTRMS) were installed in an air-conditioned trailer, on the SIRTA measurement platform. A common inlet, equipped with a $\mathrm{PM}_{10}$ head was set up through the trailer's side wall and reached $5 \mathrm{~m}$ above ground (Fig. 3). All instruments were sampling in parallel from the common inlet and the total flow was adjusted, using an extra pump, to the required $16.7 \mathrm{Lmin}^{-1}$ in order to obtain the size cut at a diameter of $10 \mu \mathrm{m}$. The SP2 and HTDMA setup was changed during two days (30-31 January 2010) when they were sampling in series (coupled setup, Fig. 3b) in order to investigate the particle mixing state as a function of the diameter and hygroscopic growth factor. The HS-PTRMS was installed in downtown Paris on the LVHP measurement platform.

\section{Results and discussion}

\subsection{Time series and source apportionment}

The time series of the data from the SP2, the HS-PTRMS, the SMPS, the HR-ToF-AMS and the aethalometer are presented in Fig. 4. The observed $\mathrm{rBC}$ mass concentration is $\sim 0.9 \mu \mathrm{g} \mathrm{m}^{-3} \pm 0.7 \mu \mathrm{g} \mathrm{m}^{-3}$ (average \pm standard deviation) although increasing to up to $4 \mu \mathrm{g} \mathrm{m}^{-3}$ for several days: 26 27 January and 7-9 February (Fig. 4a). The episodes, characterised by the highest rBC mass concentrations, will be named "Continental" period, as they were influenced by aged air masses from Continental Europe according to the retroplume analysis (Fig. 5a). The rBC mass concentrations observed in Paris are similar to previously reported values in various European highly populated cities, although different methods were used, i.e., $\sim 3 \mu \mathrm{g} \mathrm{m}^{-3}$ in Milano (Invernizzi

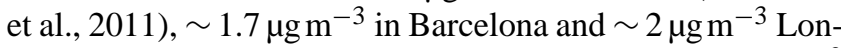
don, urban background (Reche et al., 2011) and $\sim 0.7 \mu \mathrm{g} \mathrm{m}^{-3}$ in Mexico City (Subramanian et al., 2010).

The $\mathrm{rBC}$ core mass size distribution, shown in Fig. 6 as a function of the $\mathrm{rBC}$ core mass equivalent diameter $\left(D_{\mathrm{MEV}}\right)$, is also rather stable throughout the month with a modal diameter peaking around $150 \mathrm{~nm}$ and most $\mathrm{rBC}$ mass is found between $D_{\mathrm{MEV}} \approx 100-200 \mathrm{~nm}$. An exception is the "Continental" period, with unusually large $\mathrm{rBC}$ core diameters: the modal diameter occasionally increases up to the SP2 detection limit of $\sim 500 \mathrm{~nm}$ and is on average around $230 \mathrm{~nm}$. Possible reasons for the larger core sizes during the "Continental" period as well as the influence of different air mass types will be discussed in Sect. 3.3.2.

The median thickness of non-refractory coatings on the $\mathrm{rBC}$ cores is shown in Fig. $4 \mathrm{~b}$ for particles with $\mathrm{rBC}$ core diameters between $D_{\mathrm{MEV}}=180-220 \mathrm{~nm}$. The median coating thickness is on average $\Delta_{\text {coat }}=33 \mathrm{~nm} \pm 35 \mathrm{~nm}$ (average \pm standard deviation), though peaking to over $100 \mathrm{~nm}$ during the "Continental" period.

The particle number concentration detected by the SP2 is shown in Fig. 4c, split by totally detected particles, BCcontaining particles and purely scattering particles ("purely scattering" meaning no $\mathrm{rBC}$ core or an $\mathrm{rBC}$ core below the SP2's lower detection limit of $\sim 0.5 \mathrm{fg} \mathrm{rBC}$ corresponding to a $D_{\mathrm{MEV}}$ of $80 \mathrm{~nm}$ ). Most of the time the majority of the particles are purely scattering, though occasionally almost all detected particles contain an rBC core (e.g., 18 and 25 January 2010). The total number concentration of particles with a mobility diameter $\geq 20 \mathrm{~nm}$ measured by the SMPS (thick green line in Fig. 4d) is substantially higher compared to the SP2 measurement, as many particles fall below the SP2's detection limit. Restricting the SMPS number concentration to particles with mobility diameters $\geq 140 \mathrm{~nm}$, corresponding to the lower detection limit of the SP2 for purely scattering particles, reveals excellent agreement with the SP2 $\left(r^{2}=0.85\right)$, thereby indicating good performance of both instruments. The BC-containing particles detected by the SP2 


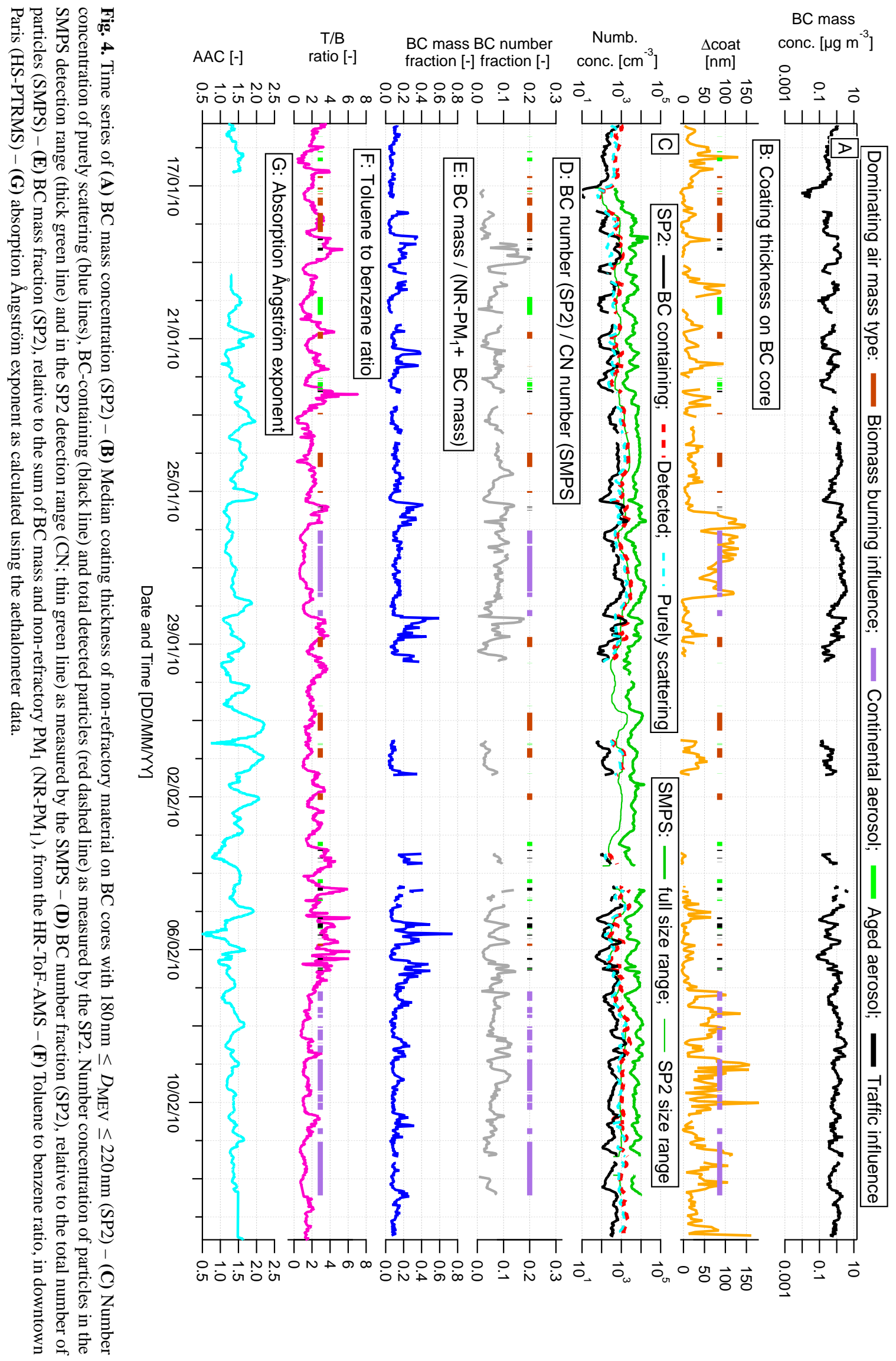



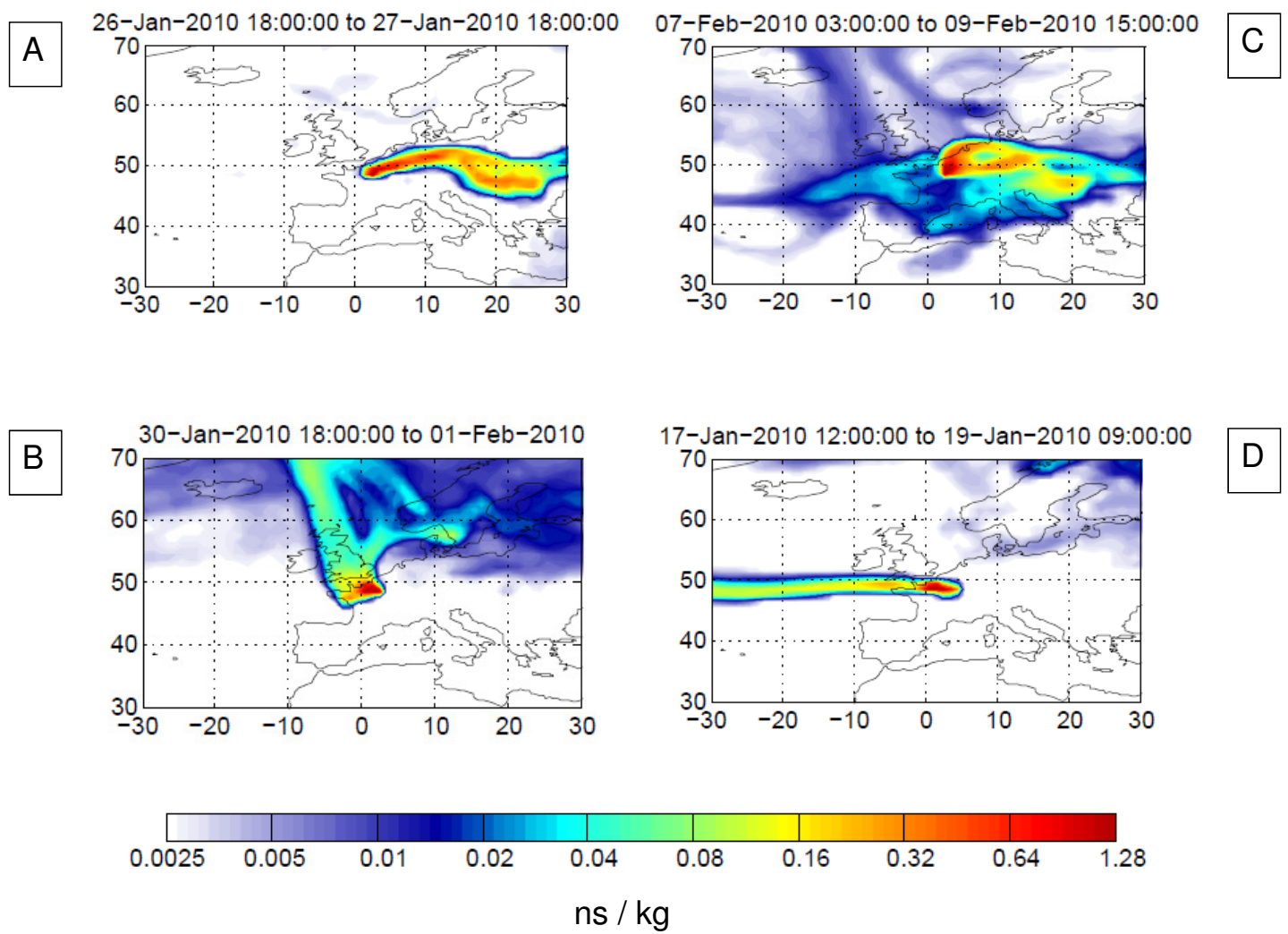

Fig. 5. Typical footprint potential emission sensitivities, from FLEXPART retroplume calculations. The X-axis represents the longitude while the Y-axis represents the latitude. Calculations are made for $(\mathbf{A})$ and $(\mathbf{C})$ the continental influence, $(\mathbf{B})$ the biomass burning influence $(\mathrm{SP} 2$ coupled to HTDMA in this case), (D) the aged aerosol influenced air mass.

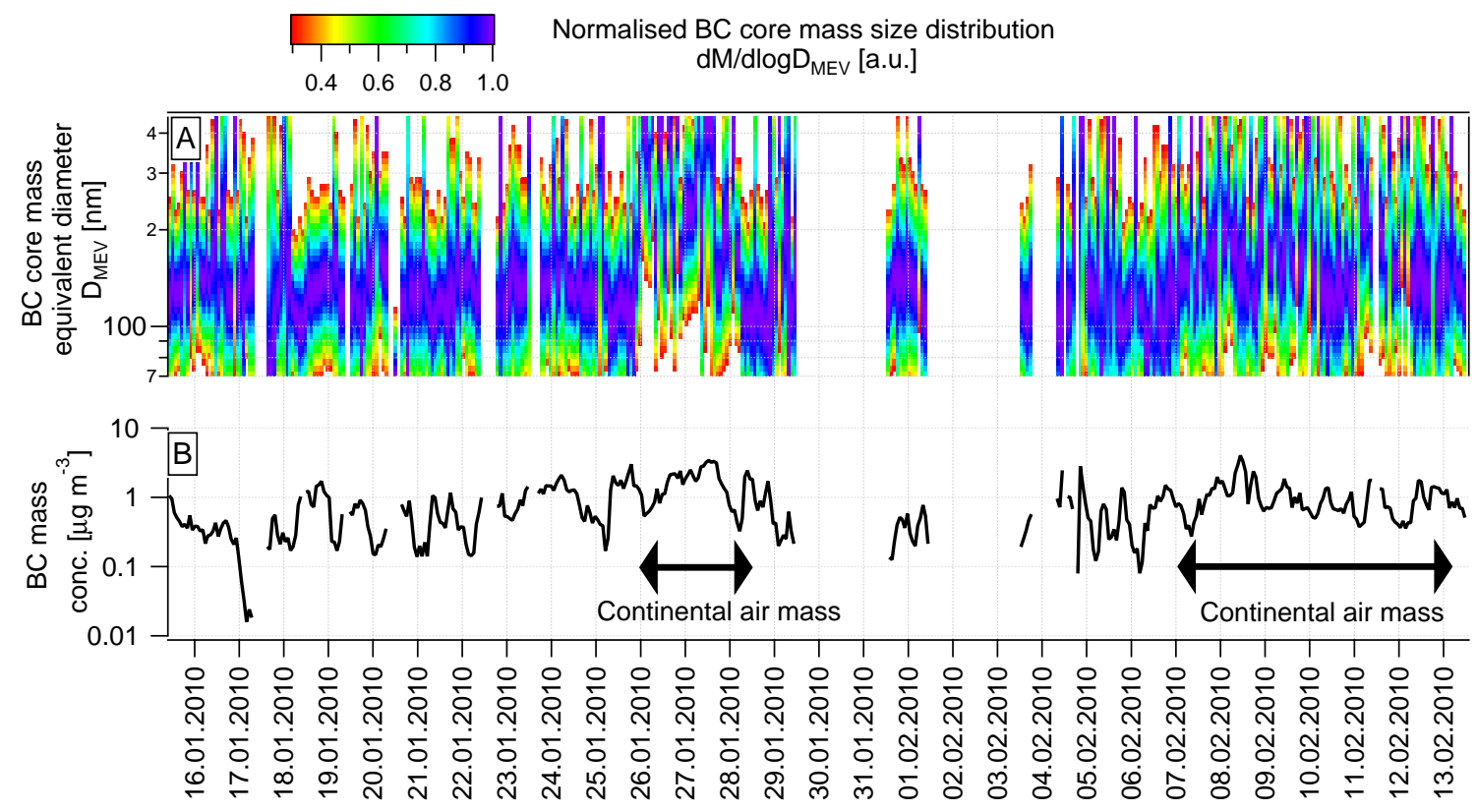

\section{Date}

Fig. 6. (A) BC mass size distribution (normalised to its maximum), as measured by the SP2. (B) BC mass concentration as measured by the SP2. 


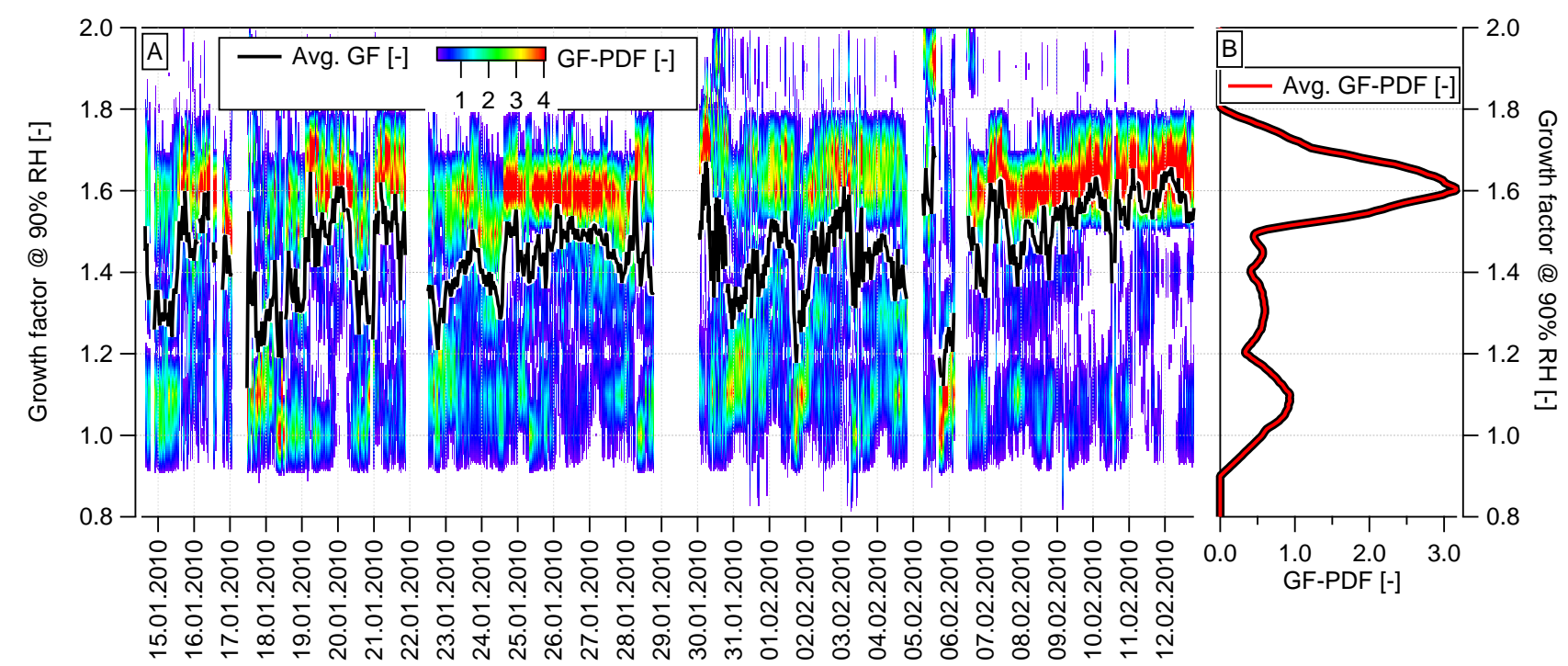

Date

Fig. 7. (A) Growth factor probability distribution function (GF-PDF; contour plot) and average growth factor (black line) as measured by the HTDMA, at $90 \% \mathrm{RH}$ and for particles with a dry mobility diameter of $D_{0} 265 \mathrm{~nm}$ dry mobility diameter. (B) GF-PDF averaged over the entire measurement period.

account for $0-15 \%$ of all particles detected by the SMPS (Fig. 4d). These numbers have to be interpreted with care as often more than $50 \%$ (by number) of the $\mathrm{rBC}$ cores fall below the SP2's lower detection limit. Nevertheless, the contribution of BC-containing particles to the total particle number concentration varies considerably and it is obvious that not all particles contain an $\mathrm{rBC}$ core, even with generous allowance for the undetected $\mathrm{rBC}$ cores. The $\mathrm{rBC}$ mass fraction in $\mathrm{PM}_{1}\left(\mathrm{PM}_{1}\right.$ calculated as the sum of NR-PM 1 measured by the HR-ToF-AMS and the $\mathrm{rBC}$ mass measured by the SP2) is higher than the rBC number fraction, accounting for $\sim 15 \%$ on average and increasing up to $40 \%$ during a few days (e.g., 28 January, 5-6 February; Fig. 4e). Several studies have reported similar contribution of $\mathrm{BC}$ to $\mathrm{PM}_{10}$ (total mass of all particles with an aerodynamic diameter $\leq 10 \mu \mathrm{m}$ ) in various European highly populated cities, although different methods were used: Milano (10-22\%; Invernizzi et al., 2011) and in London (10-26\%; Reche et al., 2011). However, lower BC mass fractions in $\mathrm{PM}_{10}$ were observed in urban background sites in Barcelona (5\%; Reche et al., 2011) and in Mexico ( 1.5\%; Subramanian et al., 2010; Querol et al., 2008) which may be due to an additional dust source. Substantial differences between the relative contributions of $\mathrm{BC}$ to $\mathrm{PM}_{1}$ and $\mathrm{PM}_{10}$ can be expected where significant dust influence occurs. Indeed $\mathrm{BC}$ mainly contributes to $\mathrm{PM}_{1}$ whereas dust mainly contributes to $\mathrm{PM}_{10}$.

The temporal variability of the aerosol hygroscopic properties is shown in Fig. 7 for the example of particles with a dry mobility diameter of $D_{0}=265 \mathrm{~nm}$. The mean GF of all particles (Fig. 7, black line) varies between 1.2 and 1.7 at $90 \% \mathrm{RH}$. The growth factor probability distribution func- tion (GF-PDF), shown as contour plot in (Fig. 7a), reveals that the variability of the mean GF is mostly driven by varying relative contributions of a more-hygroscopic mode with a modal GF of $\sim 1.6$ and non- or slightly-hygroscopic aerosol with a modal GF between 1.0 and 1.2. Moderately hygroscopic particles with GFs in the range of 1.2-1.4, are occasionally present. The more-hygroscopic mode corresponds to aged background aerosol, the non- and slightlyhygroscopic modes represent recent combustion emissions, and the moderately hygroscopic particles can most likely be attributed to moderately aged emissions of regional origin (see Sect. 3.3.5).

The observed variations of $\mathrm{rBC}$ concentrations, $\mathrm{rBC}$ properties and aerosol hygroscopicity can have many reasons such as e.g., varying contributions of different sources, dilution with background air and atmospheric ageing processes. Several studies have examined how the ratio between the toluene and benzene mixing ratios $(\mathrm{T} / \mathrm{B})$ can provide insight into sources of pollution as well as the photochemical age of the air mass with anthropogenic influence. Typically, high T/B values are associated with fresh traffic emissions while lower values are associated with more photochemical degradation. The threshold between high and low T/B values is reported to be around 2.45 with regional differences attributable to different vehicle types and fuel composition (Khoder, 2007; Hoque et al., 2008). The measurement of toluene and benzene concentrations were only performed at the LHVP site downtown Paris, $30 \mathrm{~km}$ away from the measurement site of this study. The T/B values at SIRTA are therefore not expected to be perfectly equal to those measured at the LHVP site due to different local influences. 
Nevertheless, many aerosol properties were shown to be highly correlated across the three measurement sites of the MEGAPOLI project (Beekmann et al., 2013; Crippa et al., 2013), highlighting the similarities of the air masses measured at the sites. The T/B values from downtown Paris can, therefore, be expected to provide meaningful information for the SIRTA site too. Indeed, high T/B values at the LHVP site coincide e.g., with increased $\mathrm{rBC}$ mass fraction (Fig. 4) and increased HOA mass fraction at the SIRTA site, which indicates a strong contribution from traffic emissions. Nevertheless, differences may occur for the freshly emitted aerosol and PMF results will also be used to segregate influence from different sources (see Sect. 3.3.1).

Throughout the measurement campaign, the T/B values (Fig. 4f) were low during several long periods (e.g., $\mathrm{T} / \mathrm{B} \sim 0.8 ; 26-28$ January; 7-13 February) and high during many short periods (e.g., T/B 5-7; 18 January 10.30 a.m. local time: LT; 22 January 10.50 a.m. LT; 4 February 9.50 a.m. LT). The observation of both high and low T/B values indicates different episodes with varying relative influence from fresh traffic emissions and aged air masses, respectively.

Biomass burning influence can be identified from the wavelength $(\lambda)$ dependence of the absorption coefficient $(\alpha)$ of the aerosol. $\alpha(\lambda)$ is typically a power function of $\lambda$ (see e.g., Moosmüller et al., 2011, for more details):

$\alpha(\lambda)=$ const $\lambda^{-\mathrm{AAC}}$

with the absorption Ångström coefficient (AAC) as exponent. From Eq. (5), follows (Moosmüller et al., 2011):

$\operatorname{AAC}(\lambda)=-\frac{d \ln (\alpha)}{d \ln (\lambda)}$

In this study, the AAC was determined by linearly fitting the absorption spectrum $\alpha(\lambda)$ in log-log space, using 5-min averages of the aethalometer data at all 7 wavelengths.

The observed variability of the AAC is shown in Fig. 4g. Values around 2 are typically associated with dominant influence from biomass burning emissions while values around 1 are associated with dominant influence from traffic emissions (Sandradewi et al., 2008). Strong biomass burning influence episodes (e.g., 31 January 12.00 a.m.-09.00 p.m. LT; 1 February 12.00 a.m. LT) and sharp traffic influence episodes (e.g., 31 January 02:00 p.m. LT; 3 February 12:00 p.m. LT) can be identified during the measurement campaign.

The above results revealed considerable variability of $\mathrm{rBC}$ concentrations and properties. The T/B and AAC values provide evidence of episodes with dominant influence from traffic emissions, biomass burning or aged background aerosols. This is further confirmed by statistical analysis of the organic mass spectra measured by the HR-ToF-AMS. The PMF analysis (see Sect. 2.4) identified four components of the organic aerosol: HOA, BBOA, OOA and COA each of them with considerable contributions at times (Crippa et al., 2013).
In order to assess the relative contributions of traffic and biomass burning to the $\mathrm{rBC}$ mass concentrations encountered at the SIRTA site, a simple bilinear regression model was used, which is based on the co-emission of $\mathrm{rBC}$ and organic species by the different sources. The basic assumption is that, at any time $(t)$, all $\mathrm{rBC}$ mass $\left(m_{\mathrm{rBC} \text {,tot }}\right)$ is coming from biomass burning $\left(m_{\mathrm{rBC}, \mathrm{BB}}\right)$ or traffic $\left(m_{\mathrm{rBC}}\right.$,traff $)$ emissions:

$m_{\mathrm{rBC}, \text { tot }}(t)=m_{\mathrm{rBC}, \mathrm{BB}}(t)+m_{\mathrm{rBC}, \text { traff }}(t)$

The $\mathrm{rBC}$ mass emission from biomass burning is assumed to be proportional to the mass of BBOA $\left(m_{\mathrm{BBOA}}\right)$ released, with a constant proportionality factor $a$ :

$m_{\mathrm{rBC}, \mathrm{BB}}(t)=a m_{\mathrm{BBOA}}(t)$

The rBC mass emission from traffic is assumed to be proportional to the mass of $\mathrm{HOA}\left(m_{\mathrm{HOA}}\right)$ released, with a constant proportionality factor $b$ :

$m_{\mathrm{rBC}, \text { traff }}(t)=b m_{\mathrm{HOA}}(t)$

Combining Eqs. (7)-(9) provides the bilinear regression model with the free regression parameters $a$ and $b$, which is fitted to the time-resolved $\mathrm{rBC}$ mass concentration measured by the SP2 $\left(m_{\mathrm{rBC}, \text { tot }}\right)$ and PMF results for the AMS data $\left(m_{\mathrm{HOA}}, m_{\mathrm{BBOA}}\right)$ :

$m_{\mathrm{rBC}, \text { tot }}(t)=a m_{\mathrm{BBOA}}(t)+b m_{\mathrm{HOA}}(t)$

This simple approach is expected to work best when fresh emissions give the dominant contribution to $\mathrm{rBC}$ mass, while atmospheric ageing and removal processes will vary the ratio between the PMF factors and the associated rBC mass. For this reason, the bilinear regression was done in two steps. In a first step the regression was applied to the whole dataset in order to identify the periods when the regression performs well. In a second step, the regression was repeated with restricting the data set to those times, when the first regression step predicted the measurement within $\pm 20 \%$. This particular data selection was chosen, as good regression performance is thought to be an indicator of dominant influence from primary emissions. The second regression step eventually had only a small influence on the retrieved proportionality factors $a$ and $b$, compared to those obtained after the first step. The result of the second step is reported in the following as it is thought to be more accurate.

The results of the bilinear regression are shown in Fig. 8a and b, in absolute and relative terms, respectively. The whole SP2 dataset is shown in dark blue in Fig. 8a and $\mathrm{b}$, while the data points used for the restricted regression are shown in light blue in Fig. 8b. The modelled rBC mass concentration is calculated for the whole dataset (Fig. 8a, green line) using the coefficients fitted to the restricted dataset. The simple bilinear regression performs surprisingly well for the whole dataset, with $32 \%$ and $80 \%$ of all data points falling within the limits of $\pm 20 \%$ and a factor of 2 , respectively. 

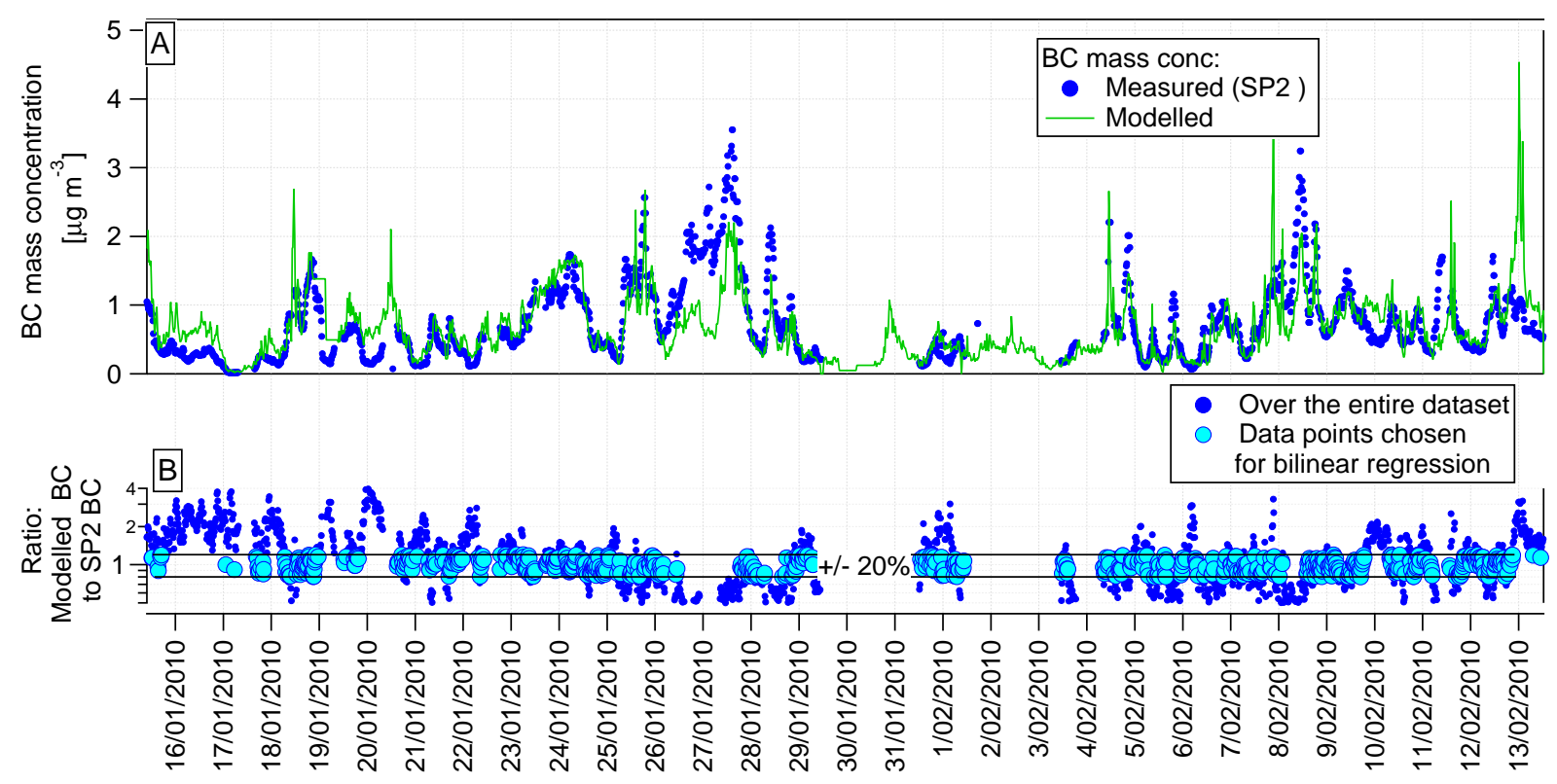

Date

Fig. 8. (A) BC mass concentration, as measured by the SP2 and modelled with a bilinear regression. (B) Relative difference between modelled and measured BC mass concentrations. Only those data points for which the modelled BC mass concentration agreed within $\pm 20 \%$ with the measured $\mathrm{BC}$ mass concentration were considered for the bilinear regression.

The model frequently underpredicts $\mathrm{rBC}$ mass concentration between 26-29 January and 4-8 February, when aged continental air mass is encountered. Overprediction is frequently obtained between 16-23 January, when an influence from both aged background air and biomass burning was observed. The regression coefficients $a$ and $b$ were found to be $0.002( \pm 0.008)$ and $0.84( \pm 0.01)$, respectively. The respective fractional contributions $\mathrm{Q}_{\text {traff }}$ and $\mathrm{Q}_{\mathrm{BB}}$ of the traffic and biomass burning emissions to the observed $\mathrm{rBC}$ mass are then obtained from the regression results with the following equations, where the bars indicate averaging over the whole dataset:

$\mathrm{Q}_{\text {traff }}=\frac{\overline{m_{\mathrm{rBC}} \text { traff }}}{\overline{m_{\mathrm{rBC}}}}$
$\mathrm{Q}_{\mathrm{BB}}=\frac{\overline{m_{\mathrm{rBC}}}}{\overline{m_{\mathrm{rBC}}}}$

The traffic and biomass burning emissions were found to account for $Q_{\text {traff }}=99.6 \%$ and $\mathrm{Q}_{\mathrm{BB}}=0.4 \%$ of the total $\mathrm{rBC}$ mass according to the simple bilinear regression model. This result is most likely biased to traffic emissions, as biomass burning is expected to give some minor contribution to $\mathrm{rBC}$ mass, too. The relative contribution of the fragment $\mathrm{m} / \mathrm{z} 60$, a marker for biomass burning aerosol, was actually somewhat higher in the HOA factor retrieved from this dataset compared to other datasets. This gives evidence that the HOA factor contains a minor biomass burning contribution, which would explain a small bias of the regression model to traffic emissions. Nevertheless, the above result indicates that traffic is the dominant source of $\mathrm{rBC}$ in Paris, which is qualitatively consistent with $74 \%$ traffic contribution, determined by Crippa et al. (2013) for the same location and time period using the observed AAC value for the source apportionment following the approach by Sandradewi et al. (2008), and with $88 \%$ traffic contribution, determined by Healy et al. (2012) for the city centre of Paris during the same time period using data from an aerosol time-of-flight mass spectrometer (ATOFMS). This result contrasts with previous observations from Holme Moss, UK (Liu et al., 2011) where solid fuel burning and traffic emission influenced equally $\mathrm{rBC}$ mass concentrations (the coefficients found were $a=0.51$ and $b=0.62$ in this case).

\subsection{Diurnal cycles}

Further insights into the influence of traffic and biomass burning emissions on aerosol concentrations and properties can be obtained by the analysis of diurnal patterns. The rBC mass concentration (Fig. 9a), the number fraction of BCcontaining particles (Fig. 9b, calculated as the number of BC-containing particles detected by the SP2 divided by the total number of particles detected by the SMPS), the HOA mass concentration (Fig. 9c) and the number fraction of nonhygroscopic particles with a $\mathrm{GF} \leq 1.05$ at $\mathrm{RH}=90 \%$ and $\mathrm{D}_{0}=265 \mathrm{~nm}$ (Fig. 9d) all exhibit very similar diurnal patterns 


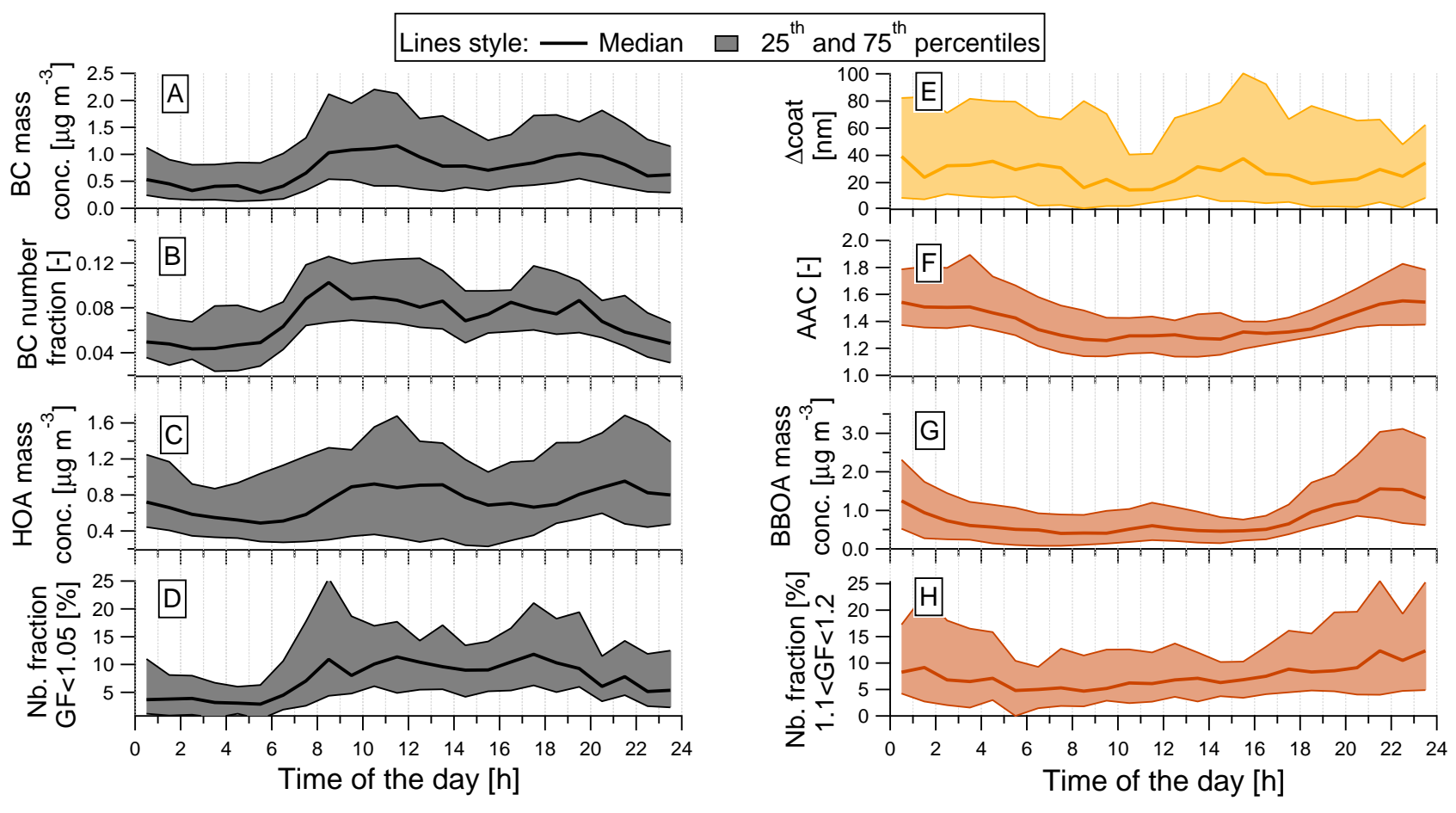

Fig. 9. Diurnal cycles of median, $25^{t h}$ and $75^{t h}$ percentiles of: (A) the BC mass concentration (SP2); (B) the relative number fraction of BC-containing particles (SP2) to the total number of particles (CN; measured by the SMPS); (C) the HOA mass concentration as retrieved from the HR-ToF-AMS measurement; (D) the number fraction of non-hygroscopic particles with GF $\leq 1.05$ (HTDMA at $90 \%$ RH); (E) the coating thickness of non-refractory matter on BC cores with a $D_{\mathrm{MEV}}$ between 180-220 nm (SP2); (F) the absorption Ångström exponent (calculated from the aethalometer data using Eq. 6); (G) the BBOA mass concentration as retrieved from the HR-ToF-AMS measurement; (H) the number fraction of slightly-hygroscopic particles with $1.1 \leq \mathrm{GF} \leq 1.2$ (HTDMA at $90 \% \mathrm{RH}$ ).

with minimal values during night-time and distinct peaks during the morning and evening rush hours. Similar diurnal variations were found for the non-hygroscopic particles, in Milano, by Baltensperger et al. (2002).

The AAC shown in Fig. 9f (with values close to 1 and 2 indicating dominating influence from traffic and biomass burning emissions, respectively) and the BBOA mass concentration shown in Fig. 9g follow a similar diurnal pattern with low values during daytime, high values during night-time and a maximum at $\sim 10.00-11.00$ p.m. LT. This pattern, which is completely different from that of traffic emissions, can most likely be attributed to a peak of domestic heating activities in the late evening hours. The number fraction of slightlyhygroscopic particles $(1.1 \leq \mathrm{GF} \leq 1.2)$ also follows a similar pattern as the $\mathrm{AAC}$ and the BBOA, thus, indicating a link between biomass burning and the emission of slightly hygroscopic aerosol which will be corroborated in Sect. 3.3.5.

The comparison of the diurnal patterns of $\mathrm{rBC}$ mass concentration with traffic and biomass burning markers provides clear evidence that traffic emissions give the dominant contribution to $\mathrm{rBC}$ mass concentrations and is consistent with the result of the bilinear regression model (Sect. 3.1). However, the evening peak of HOA is somewhat delayed compared to the evening peak of $\mathrm{rBC}$ and it is close to the BBOA peak.
This could indicate that the HOA factor contains some minor contribution from biomass burning, which would explain the over- and underestimation of the traffic and biomass burning contributions, respectively, by the bilinear regression model (Sect. 3.1).

Only a weak diurnal cycle was observed for the median thickness of non-refractory coatings on the $\mathrm{rBC}$ cores with core diameters between $D_{\mathrm{MEV}}=180-220 \mathrm{~nm}$ (Fig. 9e). Nevertheless, two minima of the median coating thickness can be identified at the morning and evening rush hours, consistent with emissions of uncoated BC-containing particles by traffic (see also Sect. 3.3.3). The fact that the observed diurnal variability is so small can either be explained with slow time scales for coating acquisition, leaving most BC-containing particles with a rather thin coating, or with a rather constant ratio of fresh and aged $\mathrm{BC}$-containing particles throughout the day. However, the latter hypothesis is not really consistent with the pronounced diurnal cycle of, e.g., the toluene to benzene mixing ratios $(\mathrm{T} / \mathrm{B})$. 


\subsection{Aerosol properties for different sources/air mass types}

Different sources of $\mathrm{BC}$ and air mass types were identified with above analyses. This section aims at investigating the properties of BC-containing particles as a function of source and air mass type. Episodes with dominant influence from traffic emissions, biomass burning emissions, aged air mass and the "continental" air mass are first identified in order to compare various aerosol and $\mathrm{rBC}$ properties between these episodes. The resulting time periods are indicated in Fig. 4 by the coloured bars.

\subsubsection{Segregation criteria}

A strong influence of biomass burning was identified using the PMF results. The time periods when the BBOA mass concentration was accounting for more than $30 \%$ of the total organic mass measured by the HR-ToF-AMS were selected as "biomass burning influenced" (brown bars in Fig. 4b, d, f). These periods coincide with AAC values close to 2, which confirm strong biomass burning influence. An example of a typical retroplume for those periods can be found in Fig. 5b, where a major contribution of the local sources can clearly be seen.

The "traffic influenced" time periods were selected using both the T/B value and the PMF results. The periods when $\mathrm{T} / \mathrm{B} \geq 3.5$ (criterion for fresh traffic emission) and when the BBOA mass accounted for less than $15 \%$ of the total organic mass concentration (criterion for minor biomass burning influence) were selected as traffic influenced (black bars in Fig. 4b, d, f).

Healy et al. (2012) already identified different time periods during the same measurement campaign, based on the same retroplume calculations. Two periods were associated with continental, aged air masses: 26-28 January and 7-15 February. This is consistent with low T/B values (Fig. 4f) and high OOA mass fractions (Crippa et al., 2013) observed here for this period, which we already named "continental" period in Sect. 3.1. Short events when BBOA and HOA accounted for more than $35 \%$ of the total organic mass, indicating substantial influence from local sources, were filtered from the continental period identified by Healy et al. (2012) in order to get undisturbed "continental" period for the following analyses (violet bars in Fig. 4b, d, f). An example of a typical retroplume experienced during those periods can be found in Fig. 5a, where a major contribution of the pollution from Eastern Europe is likely. A similar conclusion can be drawn for the second time period (7-15 February) from Fig. 5c although a slightly lower influence of the Eastern Europe pollution is observed, in favour of a high influence of the Benelux (Belgium, Netherlands, Luxembourg) area.

Finally, the time periods when the OOA mass accounts for $\geq 65 \%$ of the total organic mass, and not considering the "continental" periods, were selected to represent "aged air mass", as OOA mainly originates from secondary organic aerosol or aged primary organic aerosol. Westerly wind prevailed during this time period though with a strong potential influence of the local sources (Fig. 5d).

\subsection{2 rBC core mass size distribution}

The $\mathrm{rBC}$ core mass size distribution is reported in Fig. 10, where significant differences could be found for the four types of aerosol. The smallest $\mathrm{rBC}$ cores are observed for the traffic influence (peak at $D_{\mathrm{MEV}} \approx 100 \mathrm{~nm}$; Fig. 10a). Biomass burning and aged aerosol influenced air masses are characterised by somewhat larger $\mathrm{rBC}$ core sizes, peaking at $D_{\mathrm{MEV}} \approx 130$ and $\approx 160 \mathrm{~nm}$, respectively (Fig. 10b, c). These observations are consistent with airborne measurements by Schwarz et al. (2008a), who reported smaller BC core sizes in urban plumes compared to biomass burning plumes and aged background air. The largest $\mathrm{rBC}$ cores were observed for the continental air mass (peak at $D_{\mathrm{MEV}} \approx 200 \mathrm{~nm}$, occasionally much larger; Figs. 6a and10d). Large BC-containing particles were also observed by Healy et al. (2012) for the continental air mass with a modal particle diameter of $\sim 700$ $900 \mathrm{~nm}$. However, the ATOFMS measures the vacuum aerodynamic diameter of the whole particle ( $\mathrm{rBC}$ and coating), as opposed to the SP2 which determines the $\mathrm{rBC}$ core mass equivalent diameter. The latter quantity is smaller for equal BC-containing particles observed by either instrument, particularly for thickly coated BC-containing particles. The increased size of BC-containing particles reported by Healy et al. (2012) during the continental air mass is for a good part driven by the thickest non-refractory coatings observed by the SP2 during this period (Sect. 3.1 and Sect. 3.3.3, Fig. 11a, b). Bigger $\mathrm{rBC}$ cores in the aged continental air mass can either be the results of dominant influence from a different source or of atmospheric transformation (coagulation) and transport processes (wet removal). Shiraiwa et al. (2008) reported a slight increase of the modal $\mathrm{rBC}$ core diameter in aged air masses, however, Moteki et al. (2012) reported a decrease of the modal $\mathrm{rBC}$ core size during transport due to preferential wet removal of the bigger $\mathrm{BC}$-containing particles. A possible reason for the larger core sizes observed during the "continental" period would be the presence of a different source of BC such as coal burning.

\subsection{3 rBC core coating thickness}

The coating thickness of the BC-containing particles was determined from the SP2's light scattering and incandescence ( $\mathrm{rBC}$ mass) measurements assuming a spherical concentric core shell morphology for the Mie calculations (see Sect. 2.1.3 for details). The analysis of the coating thickness is restricted here to two different $\mathrm{rBC}$ core size ranges $\left(D_{\mathrm{MEV}}=180-220 \mathrm{~nm}\right.$ and $\left.240-280 \mathrm{~nm}\right)$ in order to investigate the size dependence of the coating thickness. 


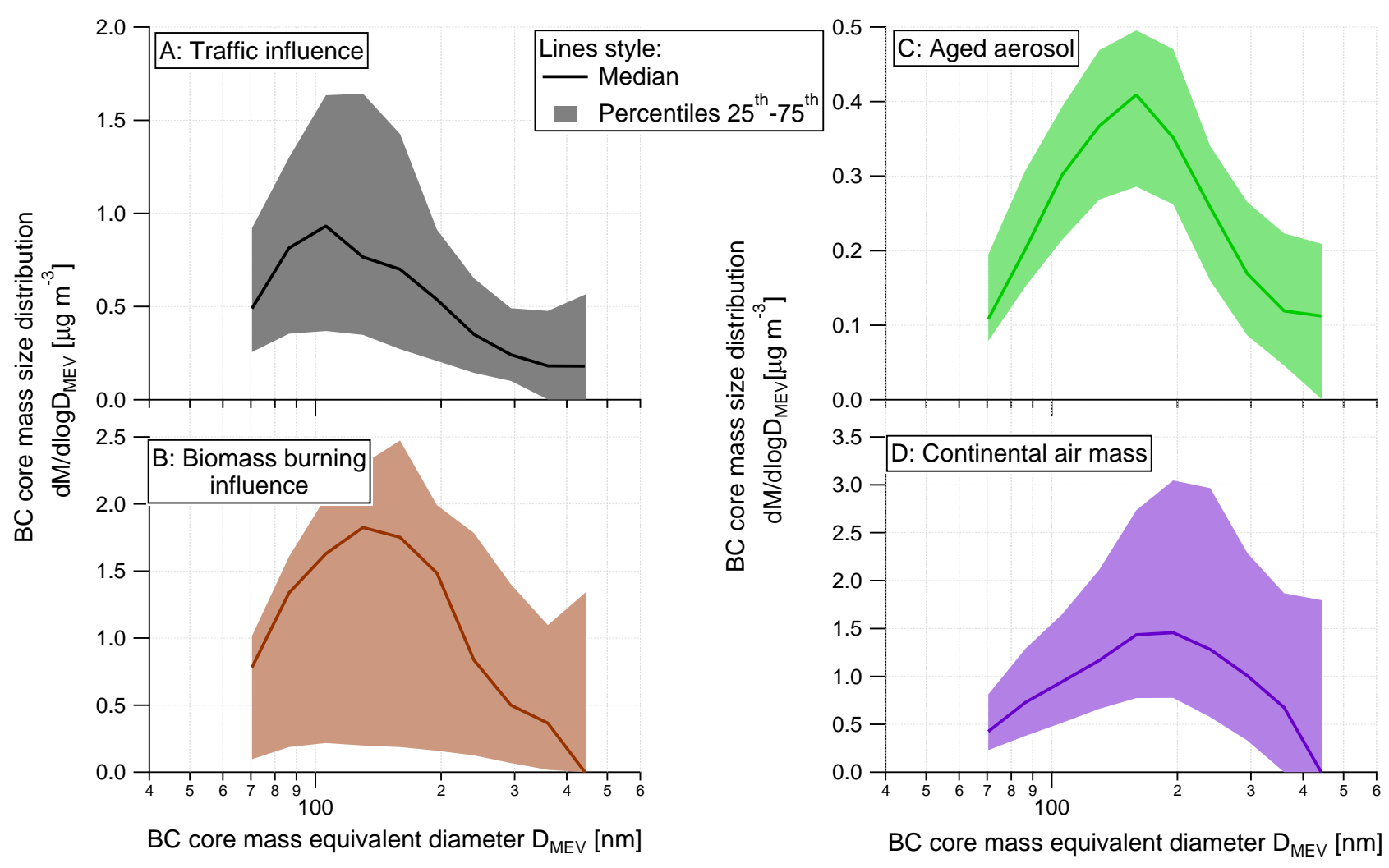

Fig. 10. Median, and $25^{t h}$ and $75^{t h}$ percentiles of BC core mass size distribution (SP2) for each air mass type.

The normalised histogram of the coating thickness of nonrefractory matter on $\mathrm{rBC}$ cores with a $D_{\mathrm{MEV}}$ between 180 $220 \mathrm{~nm}$ is reported, for the four aerosol types, in Fig. 11a. The histogram of the coating thickness for BC-containing particles observed during traffic influence has a distinct peak at slightly negative coating thickness values (consistent with essentially uncoated BC-containing particles within experimental uncertainty) although the histogram shows a "tail" which extends to higher coating thickness. Around $70 \%$ of the particles have less than $10 \mathrm{~nm}$ coating thickness, clearly indicating that $\mathrm{BC}$-containing particles emitted by traffic are essentially uncoated. The high number fraction of uncoated particles results in a median coating thickness of $2 \mathrm{~nm} \pm 10 \mathrm{~nm}$ (median \pm measurement uncertainty; see also Table 1). This is consistent with a $\mathrm{BC}$ mass fraction of $\sim 85 \%$, as reported by (Chirico et al., 2010) which translates into a coating thickness of $5 \mathrm{~nm}$ at a core diameter of $D_{\mathrm{MEV}}=200 \mathrm{~nm}$. Previous studies, using the SP2, reported a slightly bigger median coating thickness of $20-30 \mathrm{~nm}$ for urban emission that aged for a few hours $(\sim 2 \mathrm{~h}$; Schwarz et al., 2008a; Shiraiwa et al., 2008). This small difference may to some extent be caused by the short ageing time or by the fact that the previous studies were taking place in early autumn or spring with likely more active photochemistry. However, it is anyway close to the absolute uncer- tainty of coating thickness values determined with the SP2 (Sect. 2.1.3).

The coating thickness histogram for the aged aerosol air mass is also peaking at $\Delta_{\text {coat }} \approx 0 \mathrm{~nm}$ but the number fraction of BC-containing particles with medium and thick coatings $\left(\Delta_{\text {coat }}=30-200 \mathrm{~nm}\right)$ is higher compared to traffic influence. Indeed, the majority $(\sim 70 \%)$ of the particles with $\mathrm{rBC}$ $D_{\mathrm{MEV}} \approx 200 \mathrm{~nm}$ have a coating thickness of $10 \mathrm{~nm}$ or more (Fig. 11a, green solid lines). As a result, the median coating thickness of non-refractory matter on the $D_{\mathrm{MEV}} \sim 200 \mathrm{~nm}$ $\mathrm{rBC}$ cores is $\sim 44 \mathrm{~nm}$ (Fig. 11a, green dashed lines). This value is slightly lower than the average range of $48-60 \mathrm{~nm}$ reported by Schwarz et al. (2008a) and Shiraiwa et al. (2008), for aged aerosol and the same $\mathrm{rBC}$ core size range, indicating that the background aerosol observed in this study is either slightly less aged or contains a larger fraction of fresh emissions.

The coating thickness histogram of the continental air mass still peaks at $\Delta_{\text {coat }} \approx 0 \mathrm{~nm}$, similar to the aged air mass, however, the number fraction of coated particles $\left(\Delta_{\text {coat }} \geq 10 \mathrm{~nm}\right)$ is even higher $(\sim 80 \%)$, resulting in an average median coating thickness of as much as $76 \mathrm{~nm}$ (Fig. 11a, purple dashed lines). This is the highest value among the four identified air mass types and substantially larger than the $\sim 48-60 \mathrm{~nm}$ reported by Shiraiwa et al. (2008) and Schwarz 


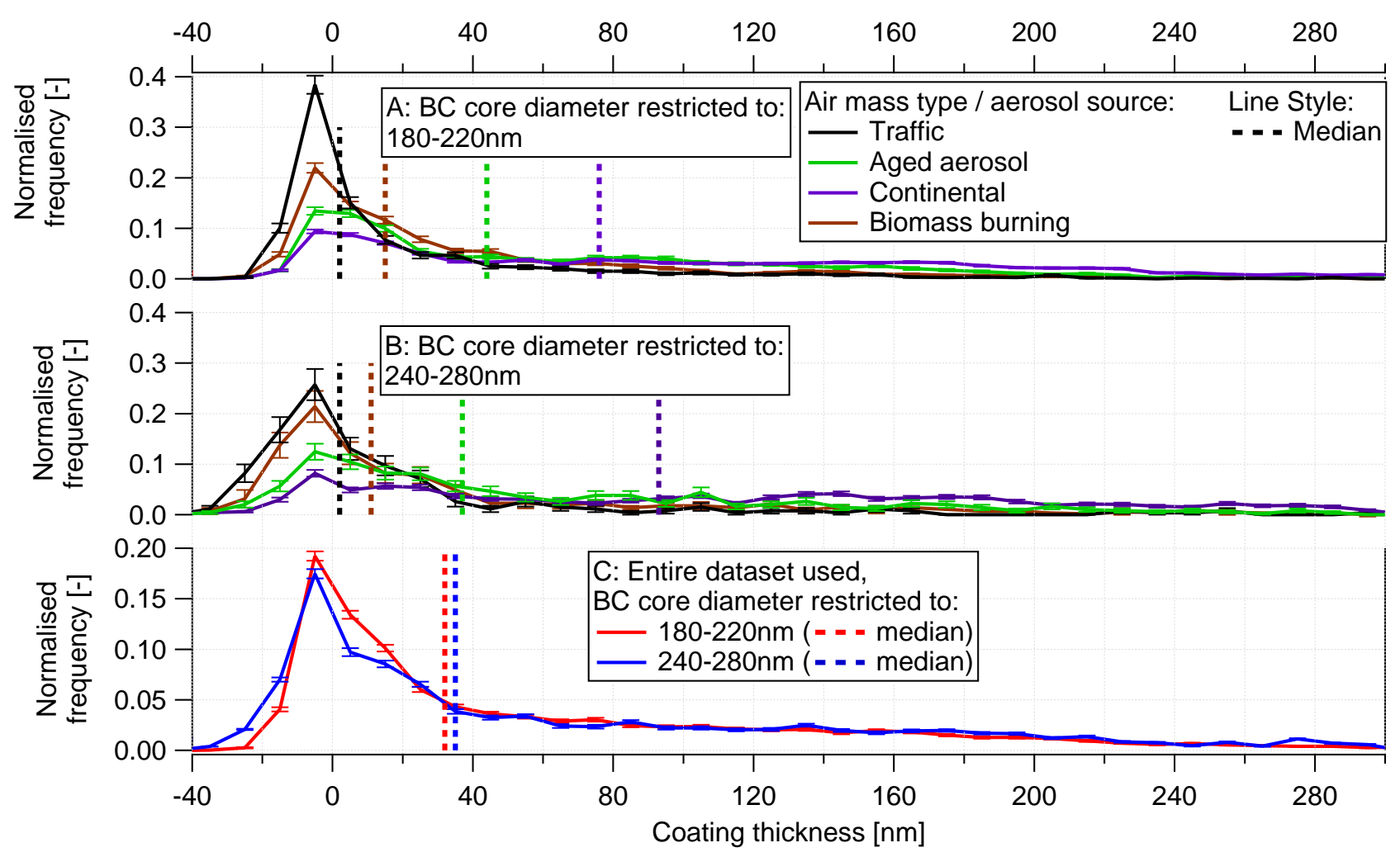

Fig. 11. Histogram (normalised by the area) of non-refractory matter coating thickness $\left(\Delta_{\text {coat }}\right)$ of BC cores with a $D_{\mathrm{MEV}}$ between $180-$ $220 \mathrm{~nm}(\mathbf{A})$ and 240-280 nm (B), for different air mass types /aerosol sources. Normalised histogram of $\Delta_{\text {coat }}$ for the entire dataset (C). The error bars represent the statistical significance $(1 / \sqrt{\text { number of points }})$.

et al. (2008a) for aged aerosol, indicating a highly aged aerosol.

In the case of biomass burning influenced air mass, the coating thickness histogram is also peaking at slightly negative values (uncoated within experimental uncertainty) and half $(\sim 53 \%)$ of the BC-containing particles have a coating thinner than $10 \mathrm{~nm}$. A substantial fraction of these uncoated particles are likely from the traffic emissions as biomass burning has been shown to give a minor contribution to $\mathrm{rBC}$ mass (Sect. 3.1 and 3.2). Almost no particles with very thick $(\geq 70 \mathrm{~nm})$ coating were observed, indicating the absence of an influence from aged aerosol. A slightly enhanced fraction of particles with a moderate coating $(\sim 20-40 \mathrm{~nm})$ was observed compared to the traffic influence. These BCcontaining particles with moderate coating are most likely from biomass burning emissions, as will be shown in more detail in Sect. 3.4. Schwarz et al. (2008a) reported an average coating of $\sim 65 \pm 12 \mathrm{~nm}$ for $\mathrm{rBC}$ from biomass burning, likely emitted by brush fires, which is much higher than the median coating thickness of $\sim 15 \mathrm{~nm}$ observed here (Fig. 11a, brown dashed lines). This substantial difference is likely caused by the difference of the biomass burning sources, i.e., brush fire emissions may have a much higher organic carbon (OC) to
$\mathrm{BC}$ ratio than those from residential heating (Heringa et al., 2011; Hennigan et al., 2011).

The coating thickness of bigger $\mathrm{rBC}$ cores with $D_{\mathrm{MEV}}=240-280 \mathrm{~nm}$ was analysed in the same way (Fig. $11 \mathrm{~b}$ and Table 1). The observed coating thickness distribution is almost equal to that for the smaller rBC cores. This applies also to the coating thickness distributions averaged over the whole campaign (Fig. 11c). On average, the fresh emissions and aged aerosol give similar contributions to the total number of BC-containing particles with $D_{\mathrm{MEV}}=200$ and $260 \mathrm{~nm}$, which results in an overall mean coating thickness of $\sim 33 \mathrm{~nm}$, in between the extreme cases. Generally, the tail of coated BC-containing particles is very broad, indicating a wide range of ageing times in the aged background aerosol. The effect of non-refractory coatings on $\mathrm{BC}$ particles on their hygroscopic growth and $\mathrm{CCN}$ activation behaviour will be discussed in Sect. 3.4.

\subsubsection{Mass absorption coefficient}

The mass absorption coefficient (MAC; also named mass absorption efficiency or mass absorption cross-section) of BCcontaining particles is defined as the light absorption cross section at a certain wavelength per unit mass of BC. The $\mathrm{MAC}$ is an important property of $\mathrm{BC}$-containing particles as 

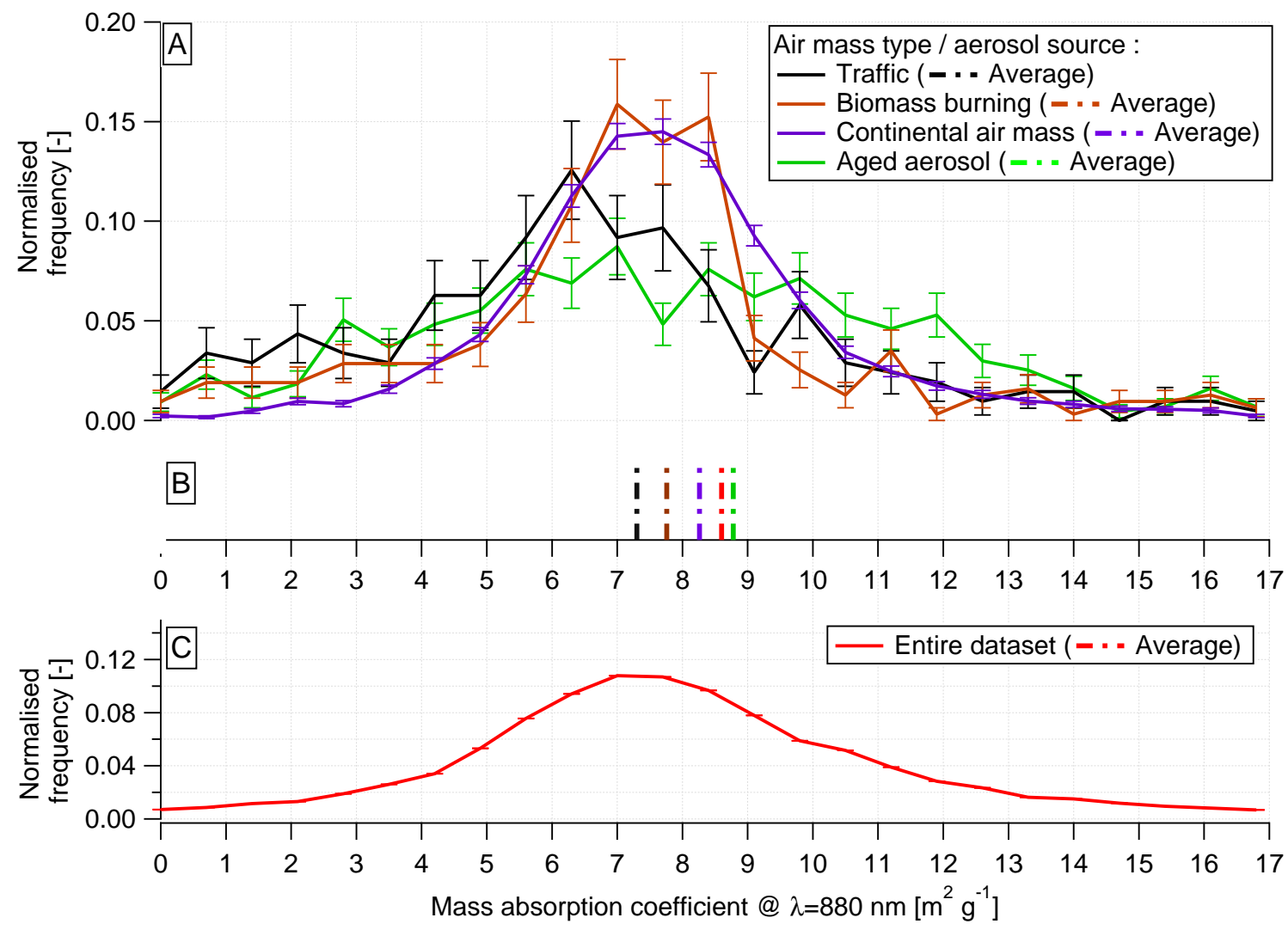

Fig. 12. Histogram (normalised to the area) of the mass absorption coefficients (MAC) for each air mass type/aerosol source (A) and calculated over the entire dataset $(\mathbf{C})$. Average MAC values corresponding to the histograms are shown in panel B. The MAC values were obtained using Eq. (6). The error bars represent the statistical significance $(1 / \sqrt{\text { number of points }})$.

Table 1. Averages of the coating thickness $\Delta_{\text {coat }}$ of non-refractory matter on BC cores with a mass equivalent diameter of $\sim 200 \mathrm{~nm}$ and $\sim 260 \mathrm{~nm}$, the mass absorption coefficient (MAC) and the toluene to benzene mixing ratios (T/B) for each air mass type or aerosol source investigated and for the entire measurement campaign.

\begin{tabular}{lcccc}
\hline $\begin{array}{l}\text { Air mass type/ } \\
\text { aerosol source }\end{array}$ & $\begin{array}{c}\mathrm{T} / \mathrm{B} \\
(-)\end{array}$ & $\begin{array}{c}\Delta_{\text {coat }}(\mathrm{nm}) \\
\text { BC core } \sim 200 \mathrm{~nm}\end{array}$ & $\begin{array}{c}\Delta_{\text {coat }}(\mathrm{nm}) \\
\text { BC core } \sim 260 \mathrm{~nm}\end{array}$ & $\begin{array}{c}\text { MAC } \\
\mathrm{m}^{2} \mathrm{~g}^{-1}\end{array}$ \\
\hline Continental & 1.21 & 76 & 93 & 8.3 \\
Aged air mass & 1.36 & 44 & 37 & 8.8 \\
Biomass burning & 2.27 & 15 & 11 & 7.8 \\
Traffic & 4.3 & 2 & 2 & 7.3 \\
Entire dataset & 2 & 32 & 35 & 8.6 \\
\hline
\end{tabular}

it is e.g., required to infer equivalent $\mathrm{BC}(\mathrm{EBC})$ mass from light absorption measurements and to calculate light absorption from modelled $\mathrm{BC}$ mass in radiative transfer simulations. The MAC is size dependent, peaking at a particle diameter equivalent to the incident wavelength and increases with coating thickness or water at high relative humidity (Schnaiter et al., 2005). Great discrepancies exist between MACs reported in literature, partially due to measurement limitations (Bond and Bergstrom, 2006). The SP2 measures the mass of $\mathrm{rBC}$ independently of the mixing state of the particles, thereby obtaining an accurate $\mathrm{rBC}$ mass measure- ment. The MAC value is then calculated as the ratio of the light absorption coefficient (measured by the aethalometer, at $\lambda=880 \mathrm{~nm}$ ) to the $\mathrm{rBC}$ mass concentration. Alternatively, the EC measurements could also have been used to calculate the MAC values. However, this would result in equal MAC values, except for a lower time resolution, as the $\mathrm{EC}$ and $\mathrm{rBC}$ measurements agree within $5 \%$ on average (Fig. 1).

The histogram (normalised to the area) of the measured MAC (10-min averages) is shown for the four air mass types (Fig. 12a) and the entire dataset (Fig. 12c). The average for each air mass type is additionally reported in Fig. 12b. The 
MAC observed for the different air mass types are very similar, but subtle differences exist (see also Table 1). The traffic influenced air mass exhibits the smallest average MAC $\left(\sim 7.3 \mathrm{~m}^{2} \mathrm{~g}^{-1}\right)$, which is consistent with the fact that the rBC cores are mainly uncoated and small (Figs. 10 and 11). Biomass burning influenced air mass is characterised by a somewhat larger average MAC $\left(\sim 7.8 \mathrm{~m}^{2} \mathrm{~g}^{-1}\right)$ than traffic, which is consistent with somewhat thicker coating and a bigger $\mathrm{rBC}$ core size. The aged aerosol shows the highest average MAC $\left(\sim 8.8 \mathrm{~m}^{2} \mathrm{~g}^{-1}\right)$, which is consistent with thicker coating compared to traffic and biomass burning. On the other hand, the average MAC of the continental aerosol $\left(\sim 8.3 \mathrm{~m}^{2} \mathrm{~g}^{-1}\right.$; Table 1$)$ is similar to biomass burning MAC, but smaller than aged aerosol. This is not quite consistent with the observation that the continental aerosol has the thickest coating. However, the continental aerosol has also been shown to have substantially larger rBC core sizes than the other air mass type, which also has, together with morphology effects, an influence on the resulting MAC. Furthermore, the continental $\mathrm{rBC}$ might have a different refractive index, if it was from a different source. The MAC values reported above for different air mass types were derived using a constant correction factor $C$ (see Sect. 2.4) for the evaluation of the aethalometer measurements. However, $C$ is known to depend on several factors including the abundance of non-BC particle components and the $\mathrm{BC}$ particle size (e.g., Cappa et al., 2008; Lack et al., 2008). The observed 20\% difference between the MAC values under the influence of traffic emissions and aged air mass may, therefore, be under- or overestimated.

The average MAC of the entire dataset is $\sim 8.6 \mathrm{~m}^{2} \mathrm{~g}^{-1}$ at $\lambda=880 \mathrm{~nm}$ (Fig. 12c and Table 1). This value is in agreement with previous measurements of the MAC in wintertime Paris by Sciare et al. (2011), who reported a value of $\sim 7.3 \mathrm{~m}^{2} \mathrm{~g}^{-1}$ at $\lambda=950 \mathrm{~nm}$, which translates to $\sim 7.9 \mathrm{~m}^{2} \mathrm{~g}^{-1}$ at $\lambda=880 \mathrm{~nm}$ (using Eq. 5 and assuming $\mathrm{AAC}=1$ ). On the other hand Healy et al. (2012) reported a substantially lower MAC value for the measurements that took place in the city centre of Paris (LHVP site) during the same time period $\left(5.1 \mathrm{~m}^{2} \mathrm{~g}^{-1}\right.$ at $\left.\lambda=950 \mathrm{~nm}\right)$, which translates to $\sim 5.5 \mathrm{~m}^{2} \mathrm{~g}^{-1}$ at $\lambda=880 \mathrm{~nm}$ ). This substantial difference may partly be explained with a relatively higher contribution of fresh traffic emissions and partly by experimental uncertainties of the light absorption and EC mass measurements. Bond and Bergstrom (2006) reported a MAC value of freshly emitted BC $\left(7.5 \mathrm{~m}^{2} \mathrm{~g}^{-1}\right.$ at $\lambda=550 \mathrm{~nm}\left(\sim 4.7 \mathrm{~m}^{2} \mathrm{~g}^{-1}\right.$ at $\left.\lambda=880 \mathrm{~nm}\right)$ for fresh uncoated BC. This is substantially lower than the $\sim 7.3 \mathrm{~m}^{2} \mathrm{~g}^{-1}$ at $\lambda=880 \mathrm{~nm}$ reported here for strong traffic influence, and the difference to other air mass types is even larger. Part of this difference may be explained by the fact that some aged background aerosol is also present during traffic influence. However, experimental uncertainties commonly associated with light absorption and $\mathrm{rBC} / \mathrm{EC}$ mass measurement may also play a role. Indeed, a constant correction factor C (see Sect. 2.4), determined from a short-time comparison with a MAAP, was used here to derive the light absorption coefficient from the aethalometer measurement. This could potentially introduce a bias of up to $40 \%$ whenever the aerosol properties differ a lot from those at the time when the correction factor $\mathrm{C}$ was determined. The width of the histogram is certainly partly due to experimental noise, but part of the observed variability also reflects true differences between the air mass types (Fig. 12a).

\subsubsection{Aerosol hygroscopicity}

The particle hygroscopicity defines its affinity to take up water. In combination with the ambient supersaturation and the particle size, it determines whether or not a particle will activate as a cloud condensation nuclei, thereby increasing its chance of being removed from the atmosphere. The hygroscopicity of different compounds varies considerably. $\mathrm{BC}$ and hydrocarbon-like organics are non-hygroscopic, oxidised organics are moderately hygroscopic and inorganic salts are the most hygroscopic aerosol components. Aerosols next to sources are often external mixtures of particles with different composition. Their hygroscopicity is, therefore, unique and important to be characterised (Rose et al., 2011). Here we investigate the hygroscopic mixing state of the aerosol for the four air mass types. A distinct mode of hygroscopic background aerosol with a GF of $\sim 1.6$ at $90 \% \mathrm{RH}$ is present during all air mass types for particles with a dry mobility diameter of $D_{0}=265 \mathrm{~nm}$ (Fig. 13a-d). The background aerosol is dominant for the aged aerosol and the continental influenced air mass, accounting for $\sim 84 \%$ of all particles in either case (Fig. 13a, b). Its contribution decreases in the traffic and the biomass burning influenced air mass, accounting for $54 \%$ and $34 \%$, respectively (Fig. 13c, d). For all periods, the relative contribution of the background aerosol decreases with decreasing particle dry size, as seen in Fig. 13 when comparing panels a-d $\left(D_{0}=265 \mathrm{~nm}\right)$ with panels e-h $\left(D_{0}=110 \mathrm{~nm}\right)$. This statement also holds for the other dry mobility diameters, which are not shown here. This observation is consistent with previous literature (Swietlicki et al., 2008).

The GF-PDFs of the aged and continental aerosols also contain, besides the most hygroscopic background mode, particles with GFs between $\sim 1-1.4$ (Fig. 13e, f), which are most likely a mixture of particles from local and regional origin with varying atmospheric age.

The GF-PDFs of the traffic influenced aerosol (Fig. 13c, g) contain a distinct non-hygroscopic mode peaking at GF between 0.9 and 1.05 , which contains $18 \%$ and $38 \%$ of the particles at $D_{0}=265$ and $110 \mathrm{~nm}$, respectively. This clearly indicates that the fresh traffic emissions are non-hygroscopic, consistent with diesel engine emission measurements by, e.g., Tritscher et al. (2011) or field measurements by Baltensperger et al. (2002), and that their relative contribution to the total particle number increases with decreasing particle size. A minor fraction of particles with GF between 


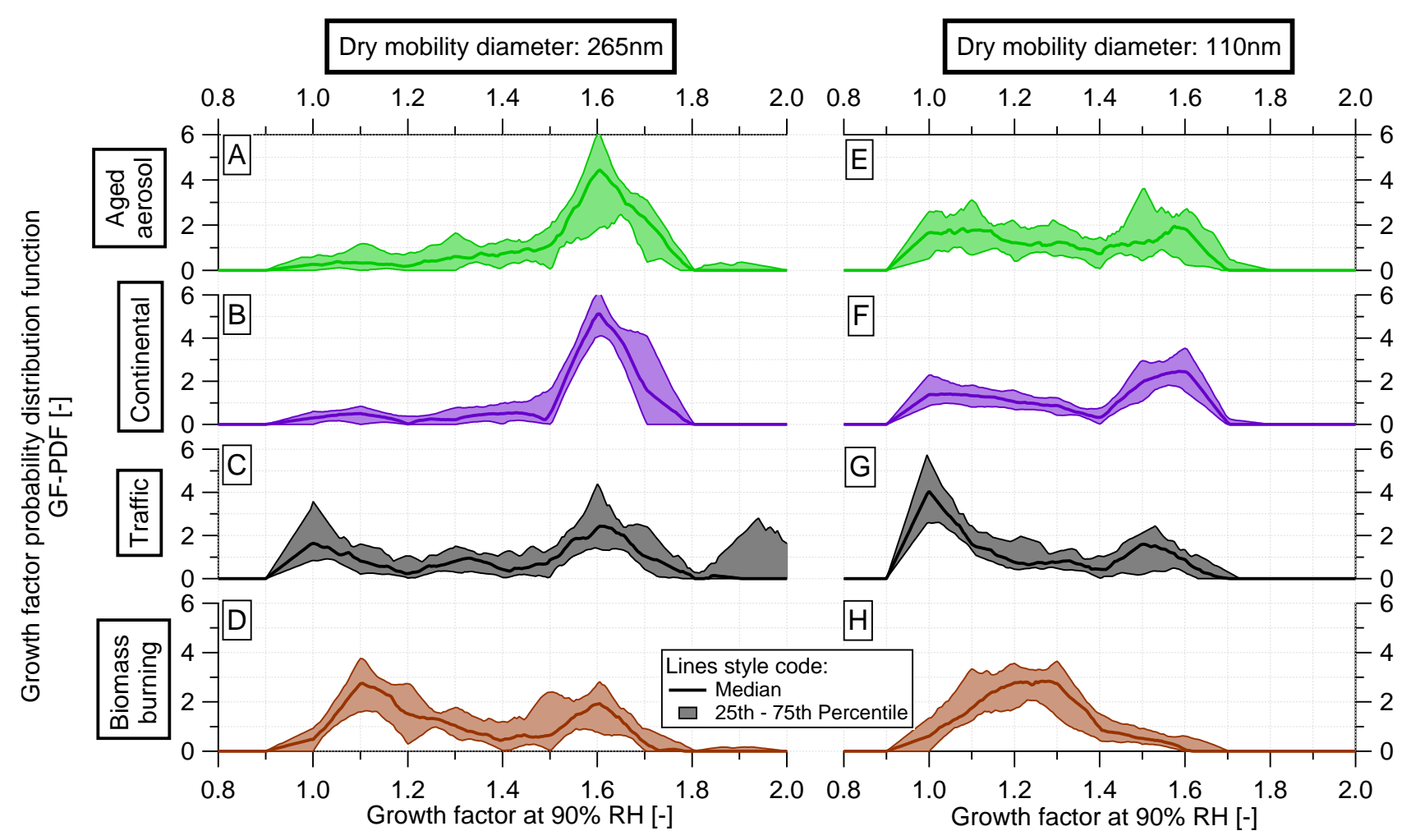

Fig. 13. Median (thicker lines) as well as $25^{\text {th }}$ and $75^{\text {th }}$ percentiles (thin lines and shading) of GF-PDF at RH=90\%, for each air mass type/aerosol source and for two dry particle mobility diameters: $265 \mathrm{~nm}$ (left panels) and $110 \mathrm{~nm}$ (right panels).

$\sim 1.1-1.4$ is also present, as for the previously described aged and continental air masses. Particles with GF between $\sim 1.8-2$ are also seen in the 75th percentiles in Fig. 13c, possibly indicating a short time period with influence from sea salt or de-icing salt.

The GF-PDF of the biomass burning influenced aerosol is, at $D_{0}=265 \mathrm{~nm}$ (Fig. 13d), a mixture of freshly emitted slightly-hygroscopic particles (peaking at $\mathrm{GF} \approx 1.1$ ) and more-hygroscopic background particles. A feature of the biomass burning influence is that the mode of freshly emitted particles is slightly more hygroscopic compared to the traffic influence. Results for $D_{0}=110 \mathrm{~nm}$ are similar, except for a vanishing contribution of the more-hygroscopic background mode and a broader and slightly more hygroscopic fresh emissions mode (peaking between GF $\approx 1.15$ 1.3). These observations are consistent with variable, but moderate hygroscopicity of fresh biomass burning emissions from different sources (e.g., Petters et al., 2009; Engelhart et al., 2012; Martin et al., 2013). Condensation of secondary organic and inorganic matter on the primary particles in the concentrated biomass burning plume may also contribute to slightly larger GFs at smaller dry sizes.

The relative importance of fresh emissions compared to the background aerosol generally increases with decreasing particle size. Total particle number is dominated by smaller particles, whereas total particle mass is dominated by larger particles. Consequently the local emissions have a stronger impact on particle number than on particle mass. It is important to account for this fact when judging the relevance of local emissions for aerosol impacts, which can either depend on particle number or on particle mass.

\subsection{Hygroscopicity and mixing state of the BC-containing particles}

The GF-PDFs discussed in Sect. 3.3.5 revealed an external mixture of the urban aerosol with a non- or slightlyhygroscopic mode, which is commonly attributed to fresh combustion emissions (Swietlicki et al., 2008), and a morehygroscopic mode formed by the background aerosol. The HTDMA alone can detect an external mixture of components with different hygroscopicity, however, an external mixture of components with similar hygroscopicity remains unresolved. In order to investigate the hygroscopic properties and mixing state of BC-containing particles in detail, the SP2 has been coupled in series with the HTDMA (see Sect. 2.6 and Fig. 3) for a short period of time on 30-31 January 2010. By coincidence this short period contained the strongest biomass burning influence of the whole campaign according to the AAC (Fig. 4g), also confirmed by a high BBOA mass fraction (not shown). This is reflected in a dominant mode of slightly-hygroscopic particles peaking at a GF 


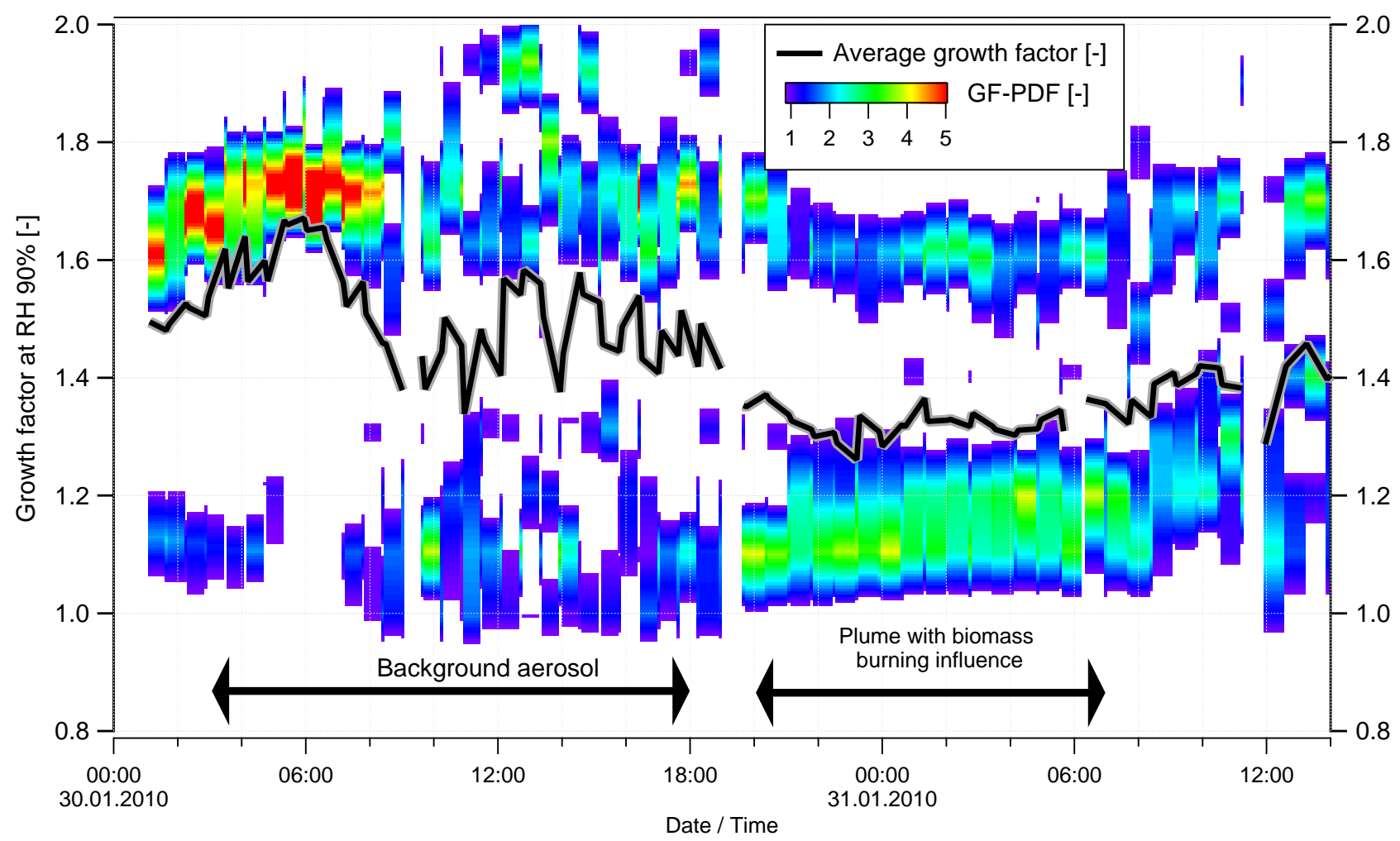

Fig. 14. GF-PDF at $90 \% \mathrm{RH}$ and $D_{0}=265 \mathrm{~nm}$ during the period when the coupled HTDMA-SP2 setup was used. Two distinct periods with dominant influence from background aerosol and biomass burning are indicated by the black arrows.

of $\sim 1.1-1.2$ between 30 January 8.00 p.m. LT and 31 January 7.00 a.m. LT (Fig. 14). A dominant influence of background aerosol, characterised by a dominance of the morehygroscopic mode and a high OOA mass fraction, was also covered by this coupled measurement on 30 January between 3.00 a.m. and 6.00 p.m. The results shown in Fig. 15 from the coupled HTDMA-SP2 measurements were separately averaged for these two periods, in the following referred to as "background aerosol" and "biomass burning influence".

The main difference between the averaged GF-PDFs of the "background aerosol" and the "biomass burning influence" is the relative abundance of more- and slightly-hygroscopic particles (blue shading in Fig. 15a, b). The SP2 reveals that most BC-containing particles (black shading) are found in the slightly-hygroscopic mode. Furthermore, the slightlyhygroscopic mode is an external mixture of particles with and without detectable $\mathrm{rBC}$ core and most $\mathrm{rBC}$ cores are found at GFs below $\sim 1.1$. This is consistent with the fact that a high number fraction of the BC particles has no or very little coating (Sect. 3.3.3). Most more-hygroscopic particles do not contain a detectable rBC core. Figure 15c, d shows the number fraction of BC-containing particles as a function of particle hygroscopicity. Very similar results are found for both "background aerosols" and "biomass burning influence": essentially every non-hygroscopic particle with a GF of $\sim 1.0$ contains an $\mathrm{rBC}$ core, while the number fraction of BC-containing particles drops sharply to $\sim 10$ $30 \%$ for $\mathrm{GF} \geq 1.1$. This result is consistent with a sharp increase of BC-containing particles at $\mathrm{GF} \leq 1.1$ observed in urban Zurich (Switzerland) by Herich et al. (2008), who operated an ATOFMS in series with a HTDMA. McMeeking et al. (2011a), who conducted coupled HTDMA-SP2 measurements in urban Manchester (UK), also observed that the dominant fraction of the low GF particles does contain rBC. However, they did observe a minor fraction of particles without a detectable $\mathrm{rBC}$ core all the way down to a GF of 1.0, which might possibly be explained by the presence of HOAdominated particles in their case. Figure 15 only shows the results for $D_{0}=265 \mathrm{~nm}$. Almost equal results with respect to external mixing of the slightly-hygroscopic mode and the number fraction of $\mathrm{rBC}$ cores as a function of the hygroscopic growth factor were also observed for $D_{0}=165$ and $110 \mathrm{~nm}$.

The mixing state of the BC-containing particles is further investigated by analysing the mean coating thickness as a function of the hygroscopic growth factor (Fig. 15e, f). The coloured lines indicate the theoretical relationship between coating thickness and hygroscopic factor for two-component particles with a total diameter of $265 \mathrm{~nm}$ that contain an insoluble $\mathrm{rBC}$ core of variable size and a soluble coating with a certain $\kappa$ value (see Sect. 2.5). The measured coating thickness (round markers) was derived from the SP2 data as 


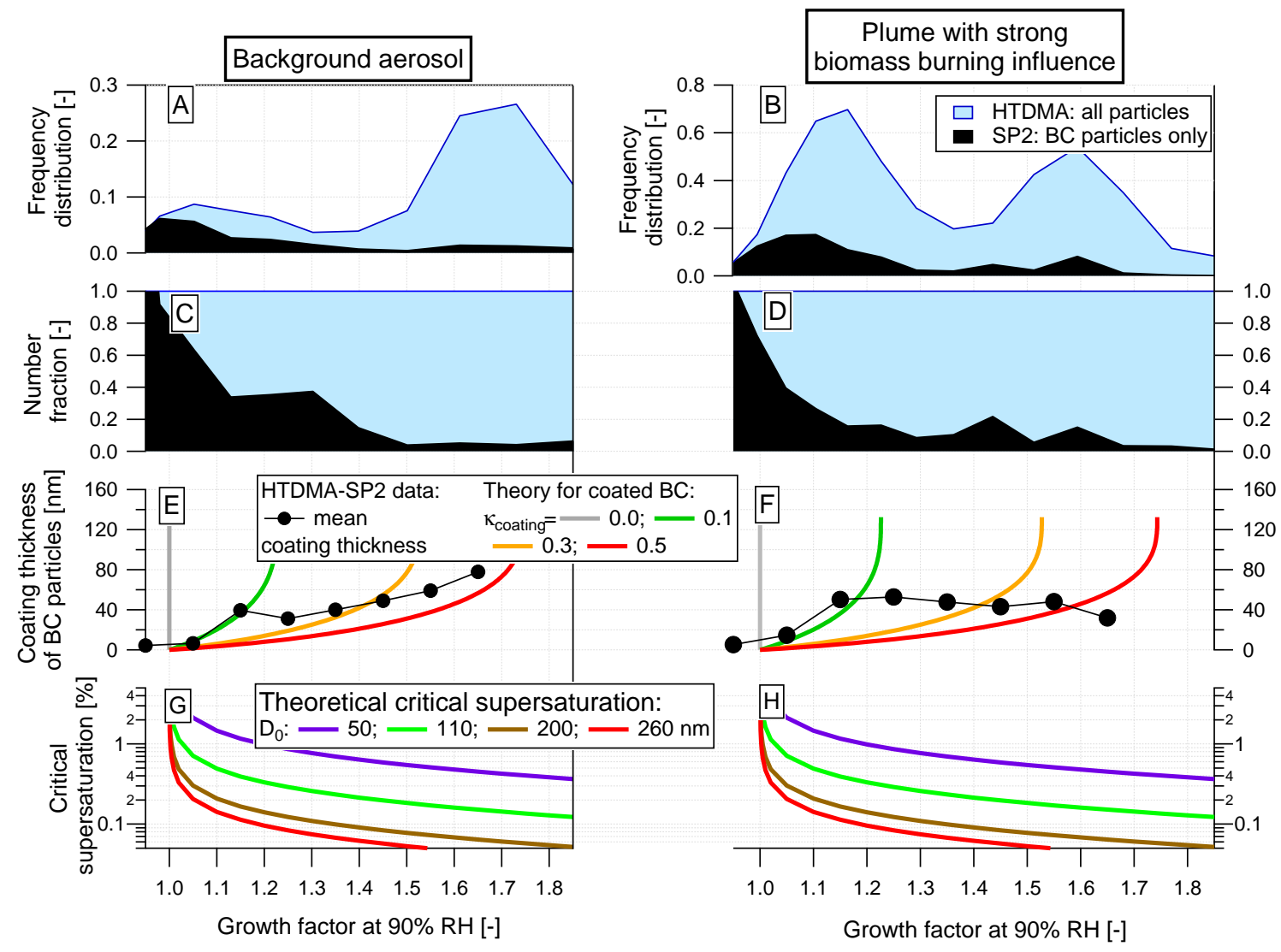

Fig. 15. Growth factor resolved properties of particles with a dry mobility diameter of $D_{0}=265$ nm obtained during the coupled HTDMASP2 setup for background (left panels) dominated and biomass burning dominated (right panels) periods. Measured GF-PDF at $90 \%$ RH (A and B) for all particles (blue shading) and BC-containing particles (black shading). Number fraction of particles (C and D) with a BC core (black shading) and without a BC core (blue shading). Mean coating thickness of non-refractory matter on the BC cores (black circles; $\mathbf{E}$ and $\mathbf{F}$ ). Theoretical GF as a function of coating thickness ( $\mathbf{E}$ and $\mathbf{F}$ ) for coating made of hydrophobic material (grey line), oxidised organics (green line), mixed organic/inorganic (orange line) and sulphate (red line). Theoretical critical supersaturations necessary for CCN activation, as a function of growth factor and dry diameters (colour code in $\mathbf{G}$ and $\mathbf{H}$ ).

explained in Sect. 2.1.3. The non-hygroscopic particles with $\mathrm{GF} \leq 1.1$ have a negligible coating, which is consistent with fresh BC-containing particles from traffic emissions (see also Figs. 11 and 13c). The coating thickness sharply increases up to $\sim 40-50 \mathrm{~nm}$ at $\mathrm{GF}=1.15$. These BC-containing particles can most likely be attributed to biomass burning emissions, as the biomass burning emissions peak at this GF (see Fig. 13d), and as the coating thickness is consistent with a $\kappa$ value of $\sim 0.1$ of the coating, which is reasonable for BBOA (Martin et al., 2013). At GFs above 1.2, the coating thickness remains almost constant (for the biomass burning influence) or increases just slightly with increasing GF (for the background aerosol), but still much flatter than the coloured lines. This indicates that $\mathrm{BC}$-containing particles in the GF range $1.2-1.6$ mainly differ by the chemical composition ( $\kappa$-value) of the coating rather than the coating thickness. The external mixture of the slightly hygroscopic mode during the biomass burning influence is an important fact for the interpretation of the impact of biomass burning emissions on $\mathrm{rBC}$ and to- tal aerosol mass. Crippa et al. (2013) showed that biomass burning emissions give a substantial contribution to the total aerosol mass averaged over the whole campaign, while the analyses presented in Sects. 3.1 and 3.2 indicate that biomass burning emissions only give a minor contribution to the $\mathrm{rBC}$ mass. This is consistent with the observation that most particles from the biomass burning emissions, which appear in the GF range of $\sim 1.1-1.3$, do not contain a detectable $\mathrm{rBC}$ core, whereas essentially all particles from traffic emissions, which appear at a GF of $\sim 1.0$, are BC-containing particles without substantial coatings.

The hygroscopic growth factor of a particle is related to the critical supersaturation required for $\mathrm{CCN}$ activation through Köhler theory. Figure $15 \mathrm{~g}$ and $\mathrm{h}$, which are identical, show this relationship for particles of different dry sizes. The curves are theoretically calculated using the singleparameter $\kappa$-Köhler theory and assuming surface tension of pure water (see Sect. 2.5). Jurányi et al. (2013) independently showed, by operating a CCN counter downstream of 
the HTDMA, that the actual hygroscopic behaviour of the Paris aerosol agrees, within experimental uncertainties, with the curves shown in Fig. 15g and h. A distinct feature of the Köhler curves is that the critical supersaturation increases sharply close to GF unity. The results presented in Fig. 15a-d show that the dominant fraction of the BC-containing particles are non- or slightly-hygroscopic. Consequently they require a substantially higher supersaturation for $\mathrm{CCN}$ activation compared to the majority of particles of equal dry size. It can, therefore, be expected that BC-containing particles are enriched in the interstitial phase of liquid clouds. Size-resolved CCN measurements showed indeed that a minor fraction of the aerosol, in polluted environments, likely BC particles, remains inactivated at rather large diameters and high supersaturations (Kuwata and Kondo, 2008; Rose et al., 2011). This composition specific activation behaviour is important to be considered in global simulations modelling atmospheric $\mathrm{rBC}$, as the wet scavenging efficiency remains a major source of uncertainty (Vignati et al., 2010).

\section{Conclusions}

The aerosol hygroscopicity and the $\mathrm{rBC}$ properties were characterised for different sources and air mass origin in Paris, one of the biggest European megacities.

The growth factor frequency distributions, characterised by distinct modes of more-hygroscopic background aerosol and non- or slightly-hygroscopic aerosol of local (or regional) origin, revealed an increase of the relative contribution of the local sources compared to the background aerosol with decreasing particle size. Different approaches to identify the sources of the particulate rBC mass in Paris indicate a dominant influence from traffic emissions, whereas biomass burning only presents a minor contribution. The mass size distribution of the $\mathrm{rBC}$ cores peaked on average at an $\mathrm{rBC}$ core mass equivalent diameter of $D_{\mathrm{MEV}} \approx 150 \mathrm{~nm}$. The BCcontaining particles were moderately coated $\left(\Delta_{\text {coat }} \approx 33 \mathrm{~nm}\right.$ on average for $\mathrm{rBC}$ cores with $D_{\mathrm{MEV}}=200 \mathrm{~nm}$ ) and a MAC of $\sim 8.6 \mathrm{~m}^{2} \mathrm{~g}^{-1}$ at $\lambda=880 \mathrm{~nm}$ was observed on average. However, distinct differences of aerosol and rBC properties were observed between different air mass types.

The traffic emissions were found to be non-hygroscopic $(\mathrm{GF} \approx 1.0$ at $\mathrm{RH}=90 \%$ ), and essentially all particles with a diameter larger than $110 \mathrm{~nm}$ contained an $\mathrm{rBC}$ core. $\mathrm{rBC}$ from traffic emissions was further characterised by literally no coating $\left(\Delta_{\text {coat }} \approx 2 \mathrm{~nm} \pm 10 \mathrm{~nm}\right)$, the smallest maximum of the $\mathrm{rBC}$ core mass size distribution $\left(D_{\mathrm{MEV}} \approx 100 \mathrm{~nm}\right)$ and the smallest MAC $\left(\sim 7.3 \mathrm{~m}^{2} \mathrm{~g}^{-1}\right.$ at $\left.\lambda=880 \mathrm{~nm}\right)$. The biomass burning aerosol, characterised by a distinct slightlyhygroscopic mode peaking at $\mathrm{GF} \approx 1.1-1.2$, was slightly more hygroscopic than the traffic emissions. Furthermore, only a minor fraction $(\leq 10 \%)$ of the slightly-hygroscopic particles with $1.1 \leq \mathrm{GF} \leq 1.2$ (with a $D_{0}=265 \mathrm{~nm}$ ) contained a detectable $\mathrm{rBC}$ core. This indicates that the impact of biomass burning emissions is relatively more important for total aerosol mass than for $\mathrm{rBC}$ mass. The $\mathrm{BC}$-containing particles from biomass burning were found to have a medium coating thickness as well as slightly larger mean core sizes and MAC values compared to traffic emissions.

The aerosol observed under the influence of aged air masses and air masses from Eastern Continental Europe was dominated by a more-hygroscopic mode peaking at $\mathrm{GF}(90 \%$ $\mathrm{RH}) \approx 1.6 .95 \%$ of the particles (with a $D_{0}=265 \mathrm{~nm}$ ) in the background mode did not contain a detectable rBC core. A significant fraction of the $\mathrm{BC}$-containing particles, except those from local emissions, which are also present, had a substantial coating with non-refractory aerosol components. MAC values of $\sim 8.8 \mathrm{~m}^{2} \mathrm{~g}^{-1}$ at $\lambda=880$ and $\sim 8.3 \mathrm{~m}^{2} \mathrm{~g}^{-1}$ at $\lambda=880 \mathrm{~nm}$ and mass mean $\mathrm{rBC}$ core diameters of $150 \mathrm{~nm}$ and $200 \mathrm{~nm}$ were observed for the aged and continental air mass types, respectively. The reason for the larger $\mathrm{rBC}$ core sizes compared to the fresh emissions - transport effects or a different $\mathrm{BC}$ source - remains unclear.

In this study, the dominant fraction of the BC-containing particles at the suburban site in Paris were found to be non- or slightly-hygroscopic. Consequently they require a higher supersaturation for $\mathrm{CCN}$ activation compared to the majority of particles of equal dry size. Considering nucleation scavenging, it can, therefore, be expected that BC-containing particles are enriched in the interstitial phase of liquid clouds, thereby decreasing their wet removal efficiency, increasing their lifetime and increasing the global BC burden and associated environmental impacts. This composition specific activation behaviour, as a function of atmospheric ageing processes should be important to be considered in global simulations modelling atmospheric $\mathrm{BC}$, as the wet scavenging efficiency remains a major source of uncertainty.

Acknowledgements. This research in the context of the MEGAPOLI project is mainly financially supported by the European Community's Framework Programme FP/2007-2011 under grant agreement no 212520 and the Swiss National Science Foundation. SIRTA, LHVP are particularly thanked for their strong support in the field.

Edited by: A. Petzold

\section{References}

Bae, M. S., Schauer, J. J., DeMinter, J. T., Turner, J. R., Smith, D., and Cary, R. A.: Validation of a semi-continuous instrument for elemental carbon and organic carbon using a thermal-optical method. Atmos. Environ., 38, 2885-2893, 2004.

Baltensperger, U., Streit, N., Weingartner, E., Nyeki, S., Prévôt, A. S. H., Van Dingenen, R., Virkkula, A., Putaud, J. P., Even, A., Brink, H. T., Blatter, A., Neftel, A., and Gäggeler, H. W.: Urban and rural aerosol characterization of summer smog events during the PIPAPO field 
campaign in Milan, Italy, J. Geophys. Res., 107, 8193, doi:10.1029/2001JD001292, 2002.

Baumgardner, D., Popovicheva, O., Allan, J., Bernardoni, V., Cao, J., Cavalli, F., Cozic, J., Diapouli, E., Eleftheriadis, K., Genberg, P. J., Gonzalez, C., Gysel, M., John, A., Kirchstetter, T. W., Kuhlbusch, T. A. J., Laborde, M., Lack, D., Müller, T., Niessner, R., Petzold, A., Piazzalunga, A., Putaud, J. P., Schwarz, J., Sheridan, P., Subramanian, R., Swietlicki, E., Valli, G., Vecchi, R., and Viana, M.: Soot reference materials for instrument calibration and intercomparisons: a workshop summary with recommendations, Atmos. Meas. Tech., 5, 1869-1887, doi:10.5194/amt-5-1869-2012, 2012.

Beekmann, M., Prévôt, A. S. H., Drewnick, F., Sciare, J., Pandis, S. N., van der Gon, H. A. C. D., Crippa, M., Freutel, F., Poulain, L., Ghersi, V., Rodriguez, E., Beirle, S., Zotter, P., von der Weiden-Reinmüller, S.-L., Bressi, M., Fountoukis, C., Petetin, H., Szidat, S., Schneider, J., Rossi, A., Haddad, I. E., Megaritis, A., Zhang, Q. J., Slowik, J. G., Moukthar, S., Kolmonen, P., Stohl, A., Eckhardt, S., Borbon, A., Gros, V., Marchand, N., Jaffrezo, J. L., Schwarzenboeck, A., Colomb, A., Wiedensohler, A., Borrmann, S., Lawrence, M., Baklanov, A., and Baltensperger, U.: Air pollution in a European megacity: the origin of fine particulate matter, submitted to Geophys. Res. Lett., 2013.

Bond, T. C. and Bergstrom, R. W.: Light absorption by carbonaceous particles: an investigative review, Aerosol Sci. Technol., 40, 27-67, 2006.

Bond, T. C., Doherty, S. J., Fahey, D. W., Forster, P. M., Berntsen, T., DeAngelo, B. J., Flanner, M. G., Ghan, S., Kärcher, B., Koch, D., Kinne, S., Kondo, Y., Quinn, P. K., Sarofim, M. C., Schultz, M. G., Schulz, M., Venkataraman, C., Zhang, H., Zhang, S., Bellouin, N., Guttikunda, S. K., Hopke, P. K., Jacobson, M. Z., Kaiser, J. W., Klimont, Z., Lohmann, U., Schwarz, J. P., Shindell, D., Storelvmo, T., Warren, S. G., and Zender, C. S.: Bounding the role of black carbon in the climate system: A scientific assessment, J. Geophys. Res., 2169-8996, doi:10.1002/jgrd.50171, 2013.

Cappa, C. D., Lack, D. A., Burkholder, J. B., and Ravishankara, A. R.: Bias in filterbased aerosol light absorption measurements due to organic aerosol loading: Evidence from laboratory measurements, Aerosol Sci. Technol., 42, 1022- 1032, doi:10.1080/02786820802389285, 2008.

Cavalli, F., Viana, M., Yttri, K. E., Genberg, J. and Putaud, J.-P.: Toward a standardised thermal-optical protocol for measuring atmospheric organic and elemental carbon: the EUSAAR protocol, Atmos. Meas. Tech., 3, 79-89, 2010

Cheng, Y. F., Berghof, M., Garland, R. M., Wiedensohler, A., Wehner, B., Müller, T., Su, H., Zhang, Y. H., Achtert, P., Nowak, A., Pöschl, U., Zhu, T., Hu, M., and Zeng, L. M.: Influence of soot mixing state on aerosol light absorption and single scattering albedo during air mass aging at a polluted regional site in Northeastern China, J. Geophys. Res., 114, D00G10, doi:10.1029/2008jd010883, 2009.

Chirico, R., DeCarlo, P. F., Heringa, M. F., Tritscher, T., Richter, R., Prévôt, A. S. H., Dommen, J., Weingartner, E., Wehrle, G., Gysel, M., Laborde, M., and Baltensperger, U.: Impact of aftertreatment devices on primary emissions and secondary organic aerosol formation potential from in-use diesel vehicles: results from smog chamber experiments, Atmos. Chem. Phys., 10,
11545-11563, doi:10.5194/acp-10-11545-2010, 2010.

Chung, S. H. and Seinfeld, J. H.: Global distribution and climate forcing of carbonaceous aerosols, J. Geophys. Res., 107, 4407, doi:10.1029/2001JD001397, 2002.

Cozic, J., Verheggen, B., Mertes, S., Connolly, P., Bower, K. Petzold, A., Baltensperger, U., and Weingartner, E.: Scavenging of black carbon in mixed phase clouds at the high alpine site Jungfraujoch, Atmos. Chem. Phys., 7, 1797-1807, doi:10.5194/acp-7-1797-2007, 2007.

Crippa, M., DeCarlo, P. F., Slowik, J. G., Mohr, C., Heringa, M., F., Chirico, R., Poulain, L., Freutel, F., Sciare, J., Cozic, J., Di Marco, C. F., Elsässer, M., José, N., Marchand, N., Abidi, E., Wiedensohler, A., Drewnick, F., Schneider, J., Borrmann, S., Nemitz, E., Zimmermann, R., Jaffrezo, J.-L., Prévôt, A. S. H., and Baltensperger, U.: Wintertime aerosol chemical composition and source apportionment of the organic fraction in the metropolitan area of Paris, Atmos. Chem. Phys., 13, 961-981, doi:10.5194/acp-13-961-2013, 2013

DeCarlo, P. F., Slowik, J. G., Worsnop, D. R., Davidovits, P., and Jimenez, J. L.: Particle morphology and density characterization by combined mobility and aerodynamic diameter measurements. Part 1: theory, Aerosol Sci. Technol., 39, 184, 2004.

DeCarlo, P. F., Kimmel, J. R., Trimborn, A., Northway, M. J., Jayne, J. T., Aiken, A. C., Gonin, M., Fuhrer, K., Horvath, T., Docherty, K. S., Worsnop, D. R., and Jimenez, J. L.: Fielddeployable, high-resolution, time-of-flight aerosol mass spectrometer, Anal. Chem., 78, 8281-8289, 2006.

DeMott, P. J., Chen, Y., Kreidenweis, S. M., Rogers, D. C., and Sherman, D. E.: Ice formation by black carbon particles, Geophys. Res. Lett., 26, 2429-2432, doi:10.1029/1999GL900580, 1999.

Dusek, U., Frank, G. P., Hildebrandt, L., Curtius, J., Schneider, J., Walter, S., Chand, D., Drewnick, F., Hings, S., Jung, D., Borrmann, S., and Andreae, M. O.: Size matters more than chemistry for cloud-nucleating ability of aerosol particles, Science, 312, 1375-1378, 2006

Engelhart, G. J., Hennigan, C. J., Miracolo, M. A., Robinson, A. L., and Pandis, S. N.: Cloud condensation nuclei activity of fresh primary and aged biomass burning aerosol, Atmos. Chem. Phys., 12, 7285-7293, doi:10.5194/acp-12-7285-2012, 2012.

Gao, R. S., Schwarz, J. P., Kelly, K. K., Fahey, D. W., Watts, L. A., Thompson, T. L., Spackman, J. R., Slowik, J. G., Cross, E. S., Han, J. H., Davidovits, P., Onasch, T. B., and Worsnop, D. R.: A novel method for estimating light-scattering properties of soot aerosols using a modified single-particle soot photometer, Aerosol Sci. Technol., 41, 125-135, 2007.

Gysel, M., Crosier, J., Topping, D. O., Whitehead, J. D., Bower, K. N., Cubison, M. J., Williams, P. I., Flynn, M. J., McFiggans, G. B., and Coe, H.: Closure study between chemical composition and hygroscopic growth of aerosol particles during TORCH2, Atmos. Chem. Phys., 7, 6131-6144, doi:10.5194/acp7-6131-2007, 2007.

Gysel, M., McFiggans, G. B., and Coe, H.: Inversion of tandem differential mobility analyser (TDMA) measurements, J. Aerosol. Sci., 40, 134-151, 2009.

Gysel, M., Laborde, M., Olfert, J. S., Subramanian, R., and Gröhn, A. J.: Effective density of Aquadag and fullerene soot black carbon reference materials used for SP2 calibration, Atmos. Meas. Tech., 4, 2851-2858, doi:10.5194/amt-4-2851-2011, 
2011.

Haeffelin, M., Barthès, L., Bock, O., Boitel, C., Bony, S., Bouniol, D., Chepfer, H., Chiriaco, M., Cuesta, J., Delanoë, J., Drobinski, P., Dufresne, J.-L., Flamant, C., Grall, M., Hodzic, A., Hourdin, F., Lapouge, F., Lemaître, Y., Mathieu, A., Morille, Y., Naud, C., Noël, V., O'Hirok, W., Pelon, J., Pietras, C., Protat, A., Romand, B., Scialom, G., and Vautard, R.: SIRTA, a groundbased atmospheric observatory for cloud and aerosol research, Ann. Geophys., 23, 253-275, doi:10.5194/angeo-23-253-2005, 2005.

Healy, R. M., Sciare, J., Poulain, L., Kamili, K., Merkel, M., Müller, T., Wiedensohler, A., Eckhardt, S., Stohl, A., SardaEstève, R., McGillicuddy, E., O'Connor, I. P., Sodeau, J. R., and Wenger, J. C.: Sources and mixing state of size-resolved elemental carbon particles in a European megacity: Paris, Atmos. Chem. Phys., 12, 1681-1700, doi:10.5194/acp-12-1681-2012, 2012.

Hennigan, C. J., Miracolo, M. A., Engelhart, G. J., May, A. A., Presto, A. A., Lee, T., Sullivan, A. P., McMeeking, G. R., Coe, H., Wold, C. E., Hao, W.-M., Gilman, J. B., Kuster, W. C., de Gouw, J., Schichtel, B. A., J. L. Collett Jr., Kreidenweis, S. M., and Robinson, A. L.: Chemical and physical transformations of organic aerosol from the photo-oxidation of open biomass burning emissions in an environmental chamber, Atmos. Chem. Phys., 11, 7669-7686, doi:10.5194/acp-11-7669-2011, 2011.

Herich, H., Kammermann, L., Gysel, M., Weingartner, E., Baltensperger, U., Lohmann, U., and Cziczo, D. J.: In situ determination of atmospheric aerosol composition as a function of hygroscopic growth, J. Geophys. Res., 113, D16213, doi:10.1029/2008JD009954, 2008.

Heringa, M. F., DeCarlo, P. F., Chirico, R., Tritscher, T., Dommen, J., Weingartner, E., Richter, R., Wehrle, G., Prévôt, A. S. H., and Baltensperger, U.: Investigations of primary and secondary particulate matter of different wood combustion appliances with a high-resolution time-of-flight aerosol mass spectrometer, Atmos. Chem. Phys., 11, 5945-5957, doi:10.5194/acp-11-59452011, 2011.

Hoque, R. R., Khillare, P. S., Agarwal, T., Shridhar, V., and Balachandran, S.: Spatial and temporal variation of BTEX in the urban atmosphere of Delhi, India, Sci. Total Environ., 392, 30-40, 2008.

Invernizzi, G., Ruprecht, A., Mazza, R., De Marco, C., Mocnik, G., Sioutas, C., and Westerdahl, D.: Measurement of black carbon concentration as an indicator of air quality benefits of traffic restriction policies within the Ecopass zone in Milan, Italy, Atmos. Environ., 45, 3522-3527, 2011.

Jacobson, M. Z.: Strong radiative heating due to the mixing state of black carbon in atmospheric aerosols, Nature, 409, 695-697, 2001.

Johnson, G. R., Ristovski, Z. D., D'Anna, B., and Morawska, L.: Hygroscopic behavior of partially volatilized coastal marine aerosols using the volatilization and humidification tandem differential mobility analyzer technique. J. Geophys. Res., 110, D20203, doi:10.1029/2004JD005657, 2005.

Jurányi, Z., Gysel, M., Tritscher, T., Weingartner, E., Laborde, M., and Baltensperger, U.: Hygroscipicity mixing state closure from Paris, Atmos. Chem. Phys. Discuss., 13, 2035-2075, 2013, http://www.atmos-chem-phys-discuss.net/13/2035/2013/.

Khoder, M. I.: Ambient levels of volatile organic compounds in the atmosphere of greater Cairo, Atmos. Environ., 41, 554-566,
2007.

Koch, D., Schulz, M., Kinne, S., McNaughton, C., Spackman, J. R., Balkanski, Y., Bauer, S., Berntsen, T., Bond, T. C., Boucher, O., Chin, M., Clarke, A., De Luca, N., Dentener, F., Diehl, T., Dubovik, O., Easter, R., Fahey, D. W., Feichter, J., Fillmore, D., Freitag, S., Ghan, S., Ginoux, P., Gong, S., Horowitz, L., Iversen, T., Kirkevåg, A., Klimont, Z., Kondo, Y., Krol, M., Liu, X., Miller, R., Montanaro, V., Moteki, N., Myhre, G., Penner, J. E., Perlwitz, J., Pitari, G., Reddy, S., Sahu, L., Sakamoto, H., Schuster, G., Schwarz, J. P., Seland, Ø., Stier, P., Takegawa, N., Takemura, T., Textor, C., van Aardenne, J. A., and Zhao, Y.: Corrigendum to "Evaluation of black carbon estimations in global aerosol models" published in Atmos. Chem. Phys., 9, 9001-9026, 2009, Atmos. Chem. Phys., 10, 79-81, doi:10.5194/acp-10-79-2010, 2010.

Kondo, Y., Sahu, L., Moteki, N., Khan, F., Takegawa, N., Liu, X., Koike, M., and Miyakawa, T.: Consistency and traceability of black carbon measurements made by laser-induced incandescence, thermal-optical transmittance, and filter-based photoabsorption techniques, Aerosol Sci. Technol., 45, 295-312, 2011.

Kuwata, M. and Kondo, Y.: Dependence of size-resolved CCN spectra on the mixing state of nonvolatile cores observed in Tokyo, J. Geophys. Res., 113, D19202, doi:10.1029/2007JD009761, 2008.

Kuwata, M., Kondo, Y., and Takegawa, N.: Critical condensed mass for activation of black carbon as cloud condensation nuclei in Tokyo. J. Geophys. Res., 114, D20202, doi:10.1029/2009JD012086, 2009.

Laborde, M., Mertes, P., Zieger, P., Dommen, J., Baltensperger, U., and Gysel, M.: Sensitivity of the Single Particle Soot Photometer to different black carbon types, Atmos. Meas. Tech., 5, 10311043, doi:10.5194/amt-5-1031-2012, 2012a.

Laborde, M., Schnaiter, M., Linke, C., Saathoff, H., Naumann, K.H., Möhler, O., Berlenz, S., Wagner, U., Taylor, J. W., Liu, D., Flynn, M., Allan, J. D., Coe, H., Heimerl, K., Dahlkötter, F., Weinzierl, B., Wollny, A. G., Zanatta, M., Cozic, J., Laj, P., Hitzenberger, R., Schwarz, J. P., and Gysel, M.: Single Particle Soot Photometer intercomparison at the AIDA chamber, Atmos. Meas. Tech., 5, 3077-3097, 2012, doi:10.5194/amt-5-30772012, 2012 b.

Lack, D. A., Cappa, C. D., Covert, D. S., Baynard, T., Massoli, P., Sierau, B., Bates, T. S., Quinn, P. K., Lovejoy, E. R., and Ravishankara, A. R.: Bias in filter-based aerosol light absorption measurements due to organic aerosol loading: Evidence from ambient measurements, Aerosol Sci. Technol., 42, 1033-1041, doi:10.1080/02786820802389277, 2008.

Lanz, V. A., Alfarra, M. R., Baltensperger, U., Buchmann, B., Hueglin, C., and Prévôt, A. S. H.: Source apportionment of submicron organic aerosols at an urban site by factor analytical modelling of aerosol mass spectra. Atmos. Chem. Phys., 7, 15031522, doi:10.5194/acp-7-1503-2007, 2007.

Lindinger, W., Hansel, A., and Jordan, A.: On-line monitoring of volatile organic compounds at pptv levels by means of protontransfer-reaction mass spectrometry (PTR-MS) - medical applications, food control and environmental research, Int. J. Mass Spectrom., 173, 191-241, 1998.

Liousse, C. and Cachier, H.: Measurement of black carbon aerosols in the atmosphere of 2 different source regions - real-time data for the Paris region and a Savanna site of the Ivory-Coast, Envi- 
ron. Technol., 13, 959-967, 1992.

Liu, D., Allan, J., Corris, B., Flynn, M., Andrews, E., Ogren, J., Beswick, K., Bower, K., Burgess, R., Choularton, T., Dorsey, J., Morgan, W., Williams, P. I., and Coe, H.: Carbonaceous aerosols contributed by traffic and solid fuel burning at a polluted rural site in Northwestern England, Atmos. Chem. Phys., 11, 1603-1619, doi:10.5194/acp-11-1603-2011, 2011.

Martin, M., Tritscher, T., Jurányi, Z., Heringa, M. F., Sierau, B., Weingartner, E., Chirico, R., Gysel, M., Prévôt, A. S. H., Baltensperger, U., and Lohmann, U.: Hygroscopicity properties of fresh and aged wood burning particles, J. Aerosol. Sci., 56, 1529, doi:10.1016/j.jaerosci.2012.08.006, 2013.

McFiggans, G., Artaxo, P., Baltensperger, U., Coe, H., Facchini, M. C., Feingold, G., Fuzzi, S., Gysel, M., Laaksonen, A., Lohmann, U., Mentel, T. F., Murphy, D. M., O’Dowd, C. D., Snider, J. R., and Weingartner, E.: The effect of physical and chemical aerosol properties on warm cloud droplet activation, Atmos. Chem. Phys., 6, 2593-2649, doi:10.5194/acp-6-25932006, 2006.

McMeeking, G. R., Good, N., Petters, M. D., McFiggans, G., and Coe, H.: Influences on the fraction of hydrophobic and hydrophilic black carbon in the atmosphere, Atmos. Chem. Phys., 11, 5099-5112, doi:10.5194/acp-11-5099-2011, 2011a.

McMeeking, G. R., Morgan, W. T., Flynn, M., Highwood, E. J., Turnbull, K., Haywood, J., and Coe, H.: Black carbon aerosol mixing state, organic aerosols and aerosol optical properties over the United Kingdom, Atmos. Chem. Phys., 11, 9037-9052, doi:10.5194/acp-11-9037-2011, 2011 b.

Moosmüller, H., Chakrabarty, R. K., Ehlers, K. M., and Arnott, W. P.: Absorption Ångström coefficient, brown carbon, and aerosols: basic concepts, bulk matter, and spherical particles, Atmos. Chem. Phys., 11, 1217-1225, doi:10.5194/acp-11-12172011, 2011.

Moteki, N. and Kondo, Y.: Effects of mixing state on black carbon measurements by laser-induced incandescence, Aerosol Sci. Technol., 41, 398-417, 2007.

Moteki, N. and Kondo, Y.: Dependence of laser-induced incandescence on physical properties of black carbon aerosols: measurements and theoretical interpretation, Aerosol Sci. Technol., 44, 663-675, 2010.

Moteki, N., Kondo, Y., and Nakamura, S.: Method to measure refractive indices of small nonspherical particles: application to black carbon particles, J. Aerosol. Sci., 41, 513-521, 2010.

Moteki, N., Kondo, Y., Oshima, N., Takegawa, N., Koike, M., Kita, K., Matsui, H., and Kajino, M.: Size dependence of wet removal of black carbon aerosols during transport from the boundary layer to the free troposphere, Geophys. Res. Lett., 39, L13802, doi:10.1029/2012GL052034, 2012.

Nakayama, T., Matsumi, Y., Sato, K., Imamura, T., Yamazaki, A., and Uchiyama, A.: Laboratory studies on optical properties of secondary organic aerosols generated during the photooxidation of toluene and the ozonolysis of $\alpha$-pinene, J. Geophys. Res., 115, D24204, doi:10.1029/2010JD014387, 2010.

Petters, M. D. and Kreidenweis, S. M.: A single parameter representation of hygroscopic growth and cloud condensation nucleus activity, Atmos. Chem. Phys., 7, 1961-1971, doi:10.5194/acp-71961-2007, 2007.

Petters, M. D., Carrico, C. M., Kreidenweis, S. M., Prenni, A. J., DeMott, P. J., Collett, J. L. J., and Moosmüller, H.: Cloud con- densation nucleation activity of biomass burning aerosol, J. Geophys. Res., 114, D22205, doi:10.1029/2009JD012353, 2009.

Petzold, A., Ogren, J. A., Fiebig, M., Laj, P., Li, S.-M., Baltensperger, U., Holzer-Popp, T., Kinne, S., Pappalardo, G., Sugimoto, N., Wehrli, C., Wiedensohler, A., and Zhang, X.-Y.: Recommendations for the interpretation of "black carbon" measurements, Atmos. Chem. Phys. Discuss., 13, 9485-9517, 2013, http://www.atmos-chem-phys-discuss.net/13/9485/2013/.

Querol, X., Pey, J., Minguillón, M. C., Pérez, N., Alastuey, A., Viana, M., Moreno, T., Bernabé, R. M., Blanco, S., Cárdenas, B., Vega, E., Sosa, G., Escalona, S., Ruiz, H., and Artíñano, B.: PM speciation and sources in Mexico during the MILAGRO-2006 Campaign, Atmos. Chem. Phys., 8, 111-128, doi:10.5194/acp8-111-2008, 2008.

Ramanathan, V. and Carmichael, G.: Global and regional climate changes due to black carbon, Nat. Geosci., 1, 221-227, 2008.

Reche, C., Querol, X., Alastuey, A., Viana, M., Pey, J., Moreno, T., Rodríguez, S., González, Y., Fernández-Camacho, R., de la Rosa, J., Dall'Osto, M., Prévôt, A. S. H., Hueglin, C., Harrison, R. M., and Quincey, P.: New considerations for PM, Black Carbon and particle number concentration for air quality monitoring across different European cities, Atmos. Chem. Phys., 11, 6207-6227, doi:10.5194/acp-11-6207-2011, 2011.

Rose, D., Gunthe, S. S., Su, H., Garland, R. M., Yang, H., Berghof, M., Cheng, Y. F., Wehner, B., Achtert, P., Nowak, A., Wiedensohler, A., Takegawa, N., Kondo, Y., Hu, M., Zhang, Y., Andreae, M. O., and Pöschl, U.: Cloud condensation nuclei in polluted air and biomass burning smoke near the megacity Guangzhou, China - Part 2: Size-resolved aerosol chemical composition, diurnal cycles, and externally mixed weakly CCN-active soot particles, Atmos. Chem. Phys., 11, 2817-2836, doi:10.5194/acp-11-2817-2011, 2011.

Ruellan, S. and Cachier, H.: Characterisation of fresh particulate vehicular exhausts near a Paris high flow road, Atmos. Environ., 35, 453-468, 2001.

Sandradewi, Prévôt, A. S. H., A. S. H., Szidat, S., Perron, N., Alfarra, M. R., Lanz, V. A., Weingartner, E., and Baltensperger, U.: Using aerosol light absorption measurements for the quantitative determination of wood burning and traffic emission contributions to particulate matter. Environ. Sci. Technol., 42, 33163323, doi:10.1021/es702253m, 2008.

Schnaiter, M., Horvath, H., Möhler, O., Naumann, K. H., Saathoff, H., and Schock, O. W.: UV-VIS-NIR spectral optical properties of soot and soot-containing aerosols, J. Aerosol. Sci., 34, 1421-1444, 2003.

Schnaiter, M., Linke, C., Möhler, O., Naumann, K. H., Saathoff, H., Wagner, R., Schurath, U., and Wehner, B.: Absorption amplification of black carbon internally mixed with secondary organic aerosol, J. Geophys. Res. Atmos., 110, D19204, doi:10.1029/2005JD006046, 2005.

Schwarz, J. P., Gao, R. S., Fahey, D. W., Thomson, D. S., Watts, L. A., Wilson, J. C., Reeves, J. M., Darbeheshti, M., Baumgardner, D. G., Kok, G. L., Chung, S. H., Schulz, M., Hendricks, J., Lauer, A., Karcher, B., Slowik, J. G., Rosenlof, K. H., Thompson, T. L., Langford, A. O., Loewenstein, M., and Aikin, K. C.: Single-particle measurements of midlatitude black carbon and light-scattering aerosols from the boundary layer to the lower stratosphere, J. Geophys. Res., 111, D16207, doi:10.1029/2006JD007076, 2006. 
Schwarz, J. P., Gao, R. S., Spackman, J. R., Watts, L. A., Thomson, D. S., Fahey, D. W., Ryerson, T. B., Peischl, J., Holloway, J. S., Trainer, M., Frost, G. J., Baynard, T., Lack, D. A., de Gouw, J. A., Warneke, C., and Del Negro, L. A.: Measurement of the mixing state, mass, and optical size of individual black carbon particles in urban and biomass burning emissions, Geophys. Res. Lett., 35, L13810, doi:10.1029/2008GL033968, 2008a.

Schwarz, J. P., Spackman, J. R., Fahey, D. W., Gao, R. S., Lohmann, U., Stier, P., Watts, L. A., Thomson, D. S., Lack, D. A., Pfister, L., Mahoney, M. J., Baumgardner, D., Wilson, J. C., and Reeves, J. M.: Coatings and their enhancement of black carbon light absorption in the tropical atmosphere, J. Geophys. Res., 113, D03203, doi: 10.1029/2007JD009042, 2008 b.

Sciare, J., d'Argouges, O., Zhang, Q. J., Sarda-Estève, R., Gaimoz, C., Gros, V., Beekmann, M., and Sanchez, O.: Comparison between simulated and observed chemical composition of fine aerosols in Paris (France) during springtime: contribution of regional versus continental emissions, Atmos. Chem. Phys., 10, 11987-12004, doi:10.5194/acp-10-11987-2010, 2010.

Sciare, J., Argouges, O., Sarda-Esteve, R., Gaimoz, C. Dolgorouky, C., Bonnaire, N., Favez, O., Bonsang, B., and Gros, V: Large contribution of water-insoluble secondary organic aerosols in the region of Paris (France) during wintertime, J. Geophys. Res., 116, 1984-2012, doi:10.1029/2011JD015756, 2011.

Shindell, D., Kuylenstierna, J. C. I., Vignati, E., van Dingenen, R., Amann, M., Klimont, Z., Anenberg, S. C., Muller, N., JanssensMaenhout, G., Raes, F., Schwartz, J., Faluvegi, G., Pozzoli, L., Kupiainen, K., Höglund-Isaksson, L., Emberson, L., Streets, D., Ramanathan, V., Hicks, K., Oanh, N. T. K., Milly, G., Williams, M., Demkine, V., and Fowler, D.: Simultaneously mitigating near-term climate change and improving human health and food security, Science, 335, 183-189, 2012.

Shiraiwa, M., Kondo, Y., Moteki, N., Takegawa, N., Sahu, L. K., Takami, A., Hatakeyama, S., Yonemura, S., and Blake, D. R.: Radiative impact of mixing state of black carbon aerosol in Asian outflow, J. Geophys. Res., 113, D24210, doi:10.1029/2008JD010546, 2008.

Solomon, S.: Intergovernmental Panel on Climate Change, and Intergovernmental Panel on Climate Change. Working Group I.: Climate Change 2007: The Physical Science Basis: Contribution of Working Group I to the Fourth Assessment Report of the Intergovernmental Panel on Climate Change, Climate Change 2007, Cambridge University Press, Cambridge, 2007.

Stephens, M., Turner, N., and Sandberg, J.: Particle identification by laser-induced incandescence in a solid-state laser cavity, Appl. Opt., 42, 3726-3736, 2003.

Stohl, A., Hittenberger, M., and Wotawa, G.: Validation of the Lagrangian particle dispersion model FLEXPART against largescale tracer experiment data, Atmos. Environ., 32, 4245-4264, doi:10.1016/S1352-2310(98)00184-8, 1998.

Stohl, A., Forster, C., Frank, A., Seibert, P., and Wotawa, G.: Technical note: The Lagrangian particle dispersion model FLEXPART version 6.2, Atmos. Chem. Phys., 5, 2461-2474, doi:10.5194/acp-5-2461-2005, 2005.

Subramanian, R., Kok, G. L., Baumgardner, D., Clarke, A., Shinozuka, Y., Campos, T. L., Heizer, C. G., Stephens, B. B., de Foy, B., Voss, P. B., and Zaveri, R. A.: Black carbon over Mexico: the effect of atmospheric transport on mixing state, mass absorption cross-section, and BC/CO ratios, Atmos. Chem. Phys.,
10, 219-237, doi:10.5194/acp-10-219-2010, 2010.

Sullivan, R. C. and Prather, K. A.: Recent advances in our understanding of atmospheric chemistry and climate made possible by on-line aerosol analysis instrumentation, Anal. Chem., 77, 38613885, 2005.

Swietlicki, E., Hansson, H. C., Hämeri, K., Svenningsson, B., Massling, A., McFiggans, G., McMurry, P. H., Petäjä, T., Tunved, P., Gysel, M., Topping, D., Weingartner, E., Baltensperger, U., Rissler, J., Wiedensohler, A., and Kulmala, M.: Hygroscopic properties of submicrometer atmospheric aerosol particles measured with H-TDMA instruments in various environments - a review, Tellus, 60B, 432-469, 2008.

Toon, O. B., Pollack, J. B., and Khare, B. N.: Optical-constants of several atmospheric aerosol species - ammonium-sulfate, aluminum-oxide, and sodium-chloride, J. Geophys. Res., 81, 5733-5748, 1976.

Tritscher, T., Jurányi, Z., Martin, M., Chirico, R., Gysel, M., Heringa, M. F., DeCarlo, P. F., Sierau, B., Prévôt, A. S. H., Weingartner, E., and Baltensperger, U.: Changes of hygroscopicity and morphology during ageing of diesel soot, Environ. Res. Lett., 6, 034026, doi:10.1088/1748-9326/6/3/034026, 2011.

Ulbrich, I. M., Canagaratna, M. R., Zhang, Q., Worsnop, D. R., and Jimenez, J. L.: Interpretation of organic components from Positive Matrix Factorization of aerosol mass spectrometric data, Atmos. Chem. Phys., 9, 2891-2918, doi:10.5194/acp-9-2891-2009, 2009.

Vignati, E., Karl, M., Krol, M., Wilson, J., Stier, P., and Cavalli, F.: Sources of uncertainties in modelling black carbon at the global scale, Atmos. Chem. Phys., 10, 2595-2611, doi:10.5194/acp-102595-2010, 2010.

Weingartner, E., Saathoff, H., Schnaiter, M., Streit, N., Bitnar, B., and Baltensperger, U.: Absorption of light by soot particles: determination of the absorption coefficient by means of aethalometers, J. Aerosol. Sci., 34, 1445-1463, 2003.

Weingartner, E., Burtscher H. and Baltensperger U.: Growth and structural change of combustion aerosols at high relative humidity, Environ. Sci. Technol., 29(12), 2982-6, 1995.

Wiedensohler, A., Birmili, W., Nowak, A., Sonntag, A., Weinhold, K., Merkel, M., Wehner, B., Tuch, T., Pfeifer, S., Fiebig, M., Fjäraa, A. M., Asmi, E., Sellegri, K., Depuy, R., Venzac, H., Villani, P., Laj, P., Aalto, P., Ogren, J. A., Swietlicki, E., Williams, P., Roldin, P., Quincey, P., Hüglin, C., FierzSchmidhauser, R., Gysel, M., Weingartner, E., Riccobono, F., Santos, S., Grüning, C., Faloon, K., Beddows, D., Harrison, R., Monahan, C., Jennings, S. G., O’Dowd, C. D., Marinoni, A., Horn, H.-G., Keck, L., Jiang, J., Scheckman, J., McMurry, P. H., Deng, Z., Zhao, C. S., Moerman, M., Henzing, B., de Leeuw, G., Löschau, G., and Bastian, S.: Mobility particle size spectrometers: harmonization of technical standards and data structure to facilitate high quality long-term observations of atmospheric particle number size distributions, Atmos. Meas. Tech., 5, 657-685, doi:10.5194/amt-5-657-2012, 2012. 